\title{
Sino-Muslim Relations: The Han, the Hui, and the Uyghurs
}

\author{
Jörg Friedrichs, University of Oxford \\ Journal of Muslim Minority Affairs, Volume 37, Number 1, 2017
}

\section{Acknowledgments}

Thanks to Nathan Brown, Michael Dillon, Matthew Erie, John Gledhill, Henrietta Harrison, Kevin Fogg, Rinku Lamba, James Leibold, and Iver Neumann for helpful suggestions and comments. Valuable research assistance by Xian Guan is gratefully acknowledged.

\begin{abstract}
Sino-Muslim relations rest upon an informal socio-spatial hierarchy according to which some Muslim groups are more of an asset and others more of a liability. In this informal hierarchy, Hui Muslims are closer to the center than any other Muslim group because they are Sinicized, seen as religiously moderate, and mostly live in proximity to non-Muslim Chinese neighbors. Central Asian Muslims, most notably Xinjiang’s Uyghurs, are more distant from China's notional center and seen as culturally more alien and prone to religious extremism. The article discusses the historical roots of this socio-spatial hierarchy and systematically examines Sino-Muslim relations in political, economic, and societal terms. It concludes that, despite some problematic features from a western-liberal perspective, the hierarchy continues to enable the Chinese majority to manage a set of otherwise challenging relationships.
\end{abstract}

\section{Keywords}

China; Muslims; Uyghurs; Hui; Xinjiang; Ningxia

Dr. Jörg Friedrichs

Associate Professor of Politics

Department of International Development

Queen Elizabeth House

3 Mansfield Road

Oxford OX1 3TB

joerg.friedrichs@qeh.ox.ac.uk 


\section{Introduction}

Chinese Xinjiang is one of only five significant territories in Asia where non-Muslims rule over a Muslim majority. After the secession of the so-called "Stans” from the former Soviet Union, the remaining four cases are Israel ruling over Palestine, India ruling over Kashmir, and Russia ruling over the North Caucasus as well as Tatarstan. Despite notorious problems, Xinjiang compares favourably to these situations with the partial exception of Tatarstan.

The same applies when considering smaller territories such as the Philippines ruling over Southern Mindanao, Burma ruling over Rakhine State, and Thailand ruling over its Southern Border Provinces. It appears that maintaining political stability in an area like Xinjiang is genuinely difficult. Hence, western criticism of China’s Xinjiang policy seems partly unfair. Whether one likes it or not, China appears to be reasonably successful in keeping control of a Muslim majority region when compared to other countries in a comparable situation.

In doing so, China can rely on an ancient Han- or Sinocentric tradition of rule over minorities. The main modality of rule has been the ethnocentric allocation of status and privilege to different groups depending on their degree of docility and acculturation. This has led to an informal socio-spatial hierarchy. In that hierarchy, so-called Hui Muslims are closer to the center than any other Muslim group. They are Sinicized, seen as religiously moderate, and most of them live in physical proximity to non-Muslim Chinese neighbors. Muslims of Central Asian extraction, such as the Turkic Uyghurs, live further away from the Chinese heartland and are considered culturally more alien and prone to religious extremism.

The most common name of China, zhongguo or zhonghua, contains the notion of "central” or “middle” (zhong, 中). Ancient Chinese cosmography, dating from about the sixth century BC, 
represented the world as five "concentric geographical zones emanating outward from the capital: royal domains, princely domains, a pacification zone, the zone of allied barbarians, and the zone of savagery.” ${ }^{1}$ The tributary system of later dynasties, such as the Ming and early Qing (ca. 1368-1841), was a similar attempt to maintain a Sinocentric “social hierarchy defined in cultural and civilizational terms”, with the Middle Kingdom located at the center and surrounded by multiple layers of "inner” and "outer” barbarians. ${ }^{2}$ Centuries later, scholars working in China continue to find concentric and multi-layered "ethnogeographies" of cultural proximity and distance, this time with the urban Han Chinese at the apex, or core. ${ }^{3}$

Related to this, China looks back to an old imperial tradition of controlling peripheral peoples through resettlement and other stratagems, and notably the classical frontier tactic of yiyi zhiyi (以夷制夷), or “using barbarians to control barbarians.”4 The fulcrum of this doctrine, which can be traced all the way to the Han dynasty (206 BC - 220 AD) and further back, is to rely on more acculturated groups of barbarians in order to defeat or hold in check the more

\footnotetext{
${ }^{1}$ Richard J. Smith, Chinese Maps: Images of "All Under Heaven" (Hong Kong: Oxford University Press, 1996), 23-24. This goes back to a passage in the Book of Documents, one of the five classics of ancient Chinese literature. See James Legge, The Chinese Classics, vol. 3 (Hongkong and London: Trübner \& Co., 1865), 142-149. ${ }^{2}$ Zhang Yongjin and Barry Buzan, "The tributary system as international society in theory and practice," Chinese Journal of International Politics 5, no. 1 (2012): 3-36, 14-15.

${ }^{3}$ Stevan Harrell, ed. Cultural Encounters on China's Ethnic Frontiers (Seattle: University of Washington Press, 1995); Susan D. Blum, Portraits of "Primitives": Ordering Human Kinds in the Chinese Nation (Lanham: Rowman \& Littlefield, 2001); Susan K. McCarthy, Communist Multiculturalism: Ethnic Revival in Southwest China (Seattle: University of Washington Press, 2009).

${ }^{4}$ I-tien Hsing, "Handai de yiyizhiyilun (The theory of 'using barbarians to control barbarians' in the Han Dynasty)," Shiyuan (Journal of Historical Review) 5, no. 2 (1974): 9-53. Compare the western imperial maxim of "divide and rule." The Romans tried to rely on the Huns to control the Goths, the Belgians on the Tutsi to control the Hutu, the British on Indian Muslims to control the Hindus, and so on.
} 
savage barbarians from the outer steppe, thus surrounding the Middle Kingdom with concentric circles of progressively less civilized ethnicities. While it seems unlikely that, today, Beijing is still pursuing yiyi zhiyi as a conscious strategy, this article shows that the related imperial legacy of a socio-spatial hierarchy of minority groups continues in various guises.

In the case of China's Muslim minorities, those falling at the lower end of the socio-spatial hierarchy defined by the Han majority (91.6 percent of Chinese citizens according to the 2010 census) understandably resent the hierarchy. Regardless, the hierarchy enables the Chinese state and Han majority to manage China's Muslim minorities by a mild form of divide and rule. The ancestral legacy of a socio-spatial hierarchy makes this possible even today, keeping the Hui apart from Central Asian Muslims and deepening the divisions between different groups of Central Asian Muslims such as the Uyghurs and the Kazaks.

The first section provides a concise demographic and historical overview of China’s Muslim minorities, justifying my analytical focus on relations between the Han, the Hui, and the Uyghurs. The subsequent three sections systematically examine the quality and management of Sino-Muslim relations in political, economic, and societal terms. Where does all of this lead us? The concluding section presents some thoughts on this, in concrete political terms.

\section{China and its Muslims}

According to the 2010 population census, China is home to 23.14 million Muslims, amounting to 1.74 percent of China's population of 1.33 billion. The largest group is the Sinicized Hui, with about 10.5 million people. The Hui are an ancient Muslim diaspora who, apart from their religion, have become acculturated to the Chinese population surrounding them. The highest concentrations of Hui Muslims live in China's northwest and southwest - notably in 
Ningxia, Gansu, Qinghai, and Yunnan. The Turkic Uyghurs are of almost equal number, with about 10 million. Unlike the Hui who are spread over most of China and speak the same language as their non-Muslim neighbors, the Turkic-speaking Uyghurs have a clear demographic concentration and homeland in China’s northwestern region of Xinjiang.

In addition to the Hui and the Uyghurs, China is home to eight smaller Muslim minorities. In descending order of population size, they are the Kazak, Dongxiang, Kyrgyz, Salar, Tajik, Uzbek, Bonan, and Tatar. All of these groups are of small numbers compared to the Hui and the Uyghurs. The third largest group, the Kazaks, are another Turkic-speaking Muslim minority rooted in Central Asia, and, like the Uyghurs, they mostly reside in Xinjiang. They amount for 6.3 percent of China’s Muslims. The fourth largest group, the Dongxiang, are of Mongolian descent and mostly live in Gansu. They account for 2.7 percent of China's Muslims. The remaining six minorities amount for as little as 1.7 percent of China’s Muslims altogether. Doctrinally, almost all Chinese Muslims belong to the Sunni denomination of Islam, including Central Asian Sufi traditions. This article focuses on the Hui and the Uyghurs given that, together, they account for almost 90 percent of Chinese Muslims (Table 1). ${ }^{5}$

\footnotetext{
${ }^{5}$ For essential background on China’s Muslims, see Michael Dillon, China's Muslims (Hong Kong: Oxford University Press, 1996). On the Hui versus the Uyghurs, see Dru C. Gladney, "Islam in China: accommodation or separatism?," China Quarterly 174(2003): 451-467; Dru C. Gladney, "Islam in China: state policing and identity politics," in Making Religion, Making the State, ed. Yoshiko Ashiwa and David L. Wank (Stanford, CA: Stanford University Press: 2009), 151-178. See also How Man Wong and Adel Awni Dajani, Islamic Frontiers of China: Peoples of the Silk Road (London: I.B. Tauris, 2011); Joanne Smith Finley, The Art of Symbolic Resistance: Uyghur Identities and Uyghur-Han Relations in Contemporary Xinjiang (Leiden: Brill, 2013). Specifically on the Kazaks, see Linda Benson and Ingvar Svanberg, China's Last Nomads: The History and Culture of China's Kazaks (Armonk, NY: M.E. Sharpe, 1998).
} 


\begin{tabular}{|l|r|r|}
\hline & \multicolumn{1}{|c|}{ Population size } & Share of Chinese Muslims (\%) \\
\hline Hui & $10,586,087$ & 45.7 \\
\hline Uyghurs & $10,069,346$ & 43.5 \\
\hline Kazaks & $1,462,588$ & 6.3 \\
\hline Dongxiang & 621,500 & 2.7 \\
\hline All others & 402,583 & 1.7 \\
\hline Total & $\mathbf{2 3 , 1 4 2 , 1 0 4}$ & $\mathbf{1 0 0 . 0}$ \\
\hline
\end{tabular}

Table 1: Absolute and relative size of China's Muslim minorities. ${ }^{6}$

\section{Xinjiang and Ningxia}

China has two autonomous Muslim regions: the Xinjiang Uyghur Autonomous Region, created in 1955, and the Ningxia Hui Autonomous Region, created in 1958. In terms of territorial administration, Xinjiang and Ningxia are at the provincial level and fall into a group with three other autonomous regions: Tibet, Inner Mongolia, and Guangxi. ${ }^{7}$

In Xinjiang, the Uyghurs are the largest ethnic group, with 47 percent. The next largest group are the Han, with 38 percent. The remaining 15 percent is made up from twelve smaller minorities, most of which are Muslim (7 percent Kazaks, 4.6 percent Hui, etc.). While the capi-

\footnotetext{
${ }^{6}$ Calculations based on National Bureau of Statistics of China, Tabulation on the 2010 Population Census of the People's Republic of China (Beijing: China Statistics Press, 2013), Part I, Table 2-1.

${ }^{7}$ China has many other autonomous units at lower administrative levels, such as the Ili Kazak Autonomous Prefecture in Xinjiang and the Linxia Hui Autonomous Prefecture in Gansu.
} 
tal city, Urumqi, is 73 percent Han, most of the southern oases ${ }^{8}$ are predominantly populated by Uyghurs as for example Kashgar city, where 84 percent of the population is Uyghur. ${ }^{9}$

In Ningxia, the majority is Han, with 64 percent. Hui Muslims are the only significant minority, with 36 percent. Especially in central and southern Ningxia, the Hui are the majority in several cities and counties. ${ }^{10}$ Ningxia is much smaller in terms of territory and population than Xinjiang, but the availability of statistical data for both regions invites comparison.

The autonomy of China's autonomous regions is severely limited, at least when compared to the constituent republics of the former Soviet Union. The latter had a last-resort right to secession and made use of that right in the early 1990s, when the Soviet Union fell apart. In China, by contrast, the integrity of the national territory is seen as sacrosanct. Accordingly, China's autonomous regions were created with no constitutional right of secession, and Beijing continues to hold a tight grip over the degree of their autonomy—especially in the case of Xinjiang. ${ }^{11}$ The creation of an independent "Uyghurstan” would be unacceptable to China. ${ }^{12}$ Maintaining control over Xinjiang is important for Beijing because, despite its small population, Xinjiang covers more than one sixth of China's territory $\left(1,660,000 \mathrm{~km}^{2}\right)$. In addition to its geostrategic significance, Xinjiang boasts important mineral resources.

\footnotetext{
${ }^{8}$ The central part of Xinjiang is an enormous desert, the Taklamakan, surrounded by oases.

${ }^{9}$ Statistics Bureau of Xinjiang Uyghur Autonomous Region, Xinjiang tongji nianjian (Xinjiang Statistical Yearbook) (Beijing: China Statistics Press, 2014), Tables 3-7 and 3-8.

${ }^{10}$ Statistics Bureau of Ningxia Hui Autonomous Region, Ningxia tongji nianjian (Ningxia Statistical Yearbook) (Beijing: China Statistics Press, 2014), Tables 4-3 and 4-9.

${ }^{11}$ Gardner Bovingdon, The Uyghurs: Strangers in Their Own Land (New York: Columbia University Press, 2010).

${ }^{12}$ Eric Hyer, "China's policy towards Uighur nationalism," Journal of Muslim Minority Affairs 26, no. 1 (2006): 75-86.
} 


\section{Historical Background}

The informal socio-spatial hierarchy of China's Muslim minorities is the result of three elements: (1) ancient Sinocentric worldviews of the Middle Kingdom being surrounded by layers of gradually more ferocious and less acculturated barbarians; (2) the legacy of imperial practices such as "using barbarians to control barbarians;” and (3) the specific ways history and especially rebellions have occurred and are remembered, with the Hui construed as more docile in comparison to the more rebellious Turkic Muslims—notably the Uyghurs. Having introduced the first two elements in the introduction, let me now deal with the third.

Historically, Muslims have lived in China for a very long time. The first Muslim traders reached the Middle Kingdom via the Silk Road and as seafaring merchants during the Tang dynasty (618-907 AD). Another important wave occurred under the Yuan (1271-1368) when Mongol overlords relied on troops from Central Asia. Later, during the Qing (1644-1911), vast territories populated by Central Asian Muslims were incorporated into the Empire. ${ }^{13}$

\section{The Hui}

Despite considerable variation on the degree of their acculturation, the people today classified as Hui are essentially Chinese-speaking practitioners of Islam. Having always been a vulner-

\footnotetext{
${ }^{13}$ Jonathan N. Lipman, Familiar Strangers: A History of Muslims in Northwest China (Seattle: University of Washington Press, 1997); Michael Dillon, China's Muslim Hui Community: Migration, Settlement and Sects (Richmond, UK: Curzon, 1999); Fan Ke, "Maritime Muslims and Hui identity: a south Fujian case," Journal of Muslim Minority Affairs 21, no. 2 (2001): 309-332; Fan Ke, "Ups and downs: local Muslim history in South China," Journal of Muslim Minority Affairs 23, no. 1 (2003): 63-87; James A. Millward, Eurasian Crossroads: A History of Xinjiang (London: Hurst, 2007).
} 
able religious diaspora surrounded by hegemonic Chinese culture and subject to non-Muslim rule, the Hui represent a remarkable adaptation of Islam to Chinese circumstances. ${ }^{14}$

Over the first 1,000 years or so after reaching China from the Middle East and Central Asia, most Muslims lost their vernacular languages and cultural traits, as it would have been impossible for them to maintain regular links with their distant areas of origin. Gradually, their progeny lost their ethnic traits through intermarriage with local women. ${ }^{15}$ Religious conversion may have played a (probably limited) role. Today, the descendants of China's acculturated Muslims are known as the Hui although some prefer the term “Sino-Muslims.”16

Until the republican era, under the Kuomintang, the term Hui denoted any Muslim regardless of ethnicity, but the communist regime broke with that tradition. Since the mid-1950s, the Hui have been classified not as a religious group but as one of China’s 55 ethnic minority groups (minzu), alongside other Muslim and non-Muslim minorities such as the Uyghurs, Tibetans, and Koreans. The ethnonym Hui is problematic because it deemphasizes Islam and inserts an ethnic element into an otherwise religious identity, despite the fact that most Hui are ethnically indistinguishable from the Han. Yet the category has stuck. ${ }^{17}$

\footnotetext{
${ }^{14}$ Dru C. Gladney, Muslim Chinese: Ethnic Nationalism in the People's Republic, 2nd ed. (Cambridge, MA: Cambridge University Press, 1996); Dru C. Gladney, Dislocating China: Reflections on Muslims, Minorities, and Other Subaltern Subjects (Chicago: University of Chicago Press, 2004).

${ }^{15}$ Gladney, "Islam in China: accommodation or separatism?," 464; Gladney, "Islam in China: state policing and identity politics," 160.

${ }^{16}$ Lipman, Familiar Strangers: A History of Muslims in Northwest China.

${ }^{17}$ Gladney, Muslim Chinese: Ethnic Nationalism in the People's Republic.
} 
Centuries before their official classification as Hui, interactions with the political establishment and its cultured elites had already left their imprint on China’s Sinicized Muslims. This is exemplified by a collection of writings from the early 18th century called the Han Kitab. ${ }^{18}$ A significant part of that body of literature portrays Islam apologetically as compatible with Confucian principles of social order and political doctrine. ${ }^{19}$ Especially Liu Zhi, the most famous writer of the Han Kitab, emphasized allegiance to Confucian hierarchy, including loyalty to the Emperor, as the duty of any good Muslim, while deemphasizing notions that might have challenged Confucian hierarchy and loyalty, such as jihad or allegiance to the ummah. ${ }^{20}$ This was the beginning of a lasting tradition of trying to present Islam in ways compatible with China’s ruling ideology—Confucian first, republican later, then communist. ${ }^{21}$

The Hui are Chinese and Muslim at the same time, and this obliges them to constantly negotiate the tension between their twin belongings. ${ }^{22}$ It is debatable whether and to what extent the history of so-called "Hui rebellions" is an aspect of this negotiation. On the one hand, historians argue that revolts, such as those during the transition from the Ming to the Qing dynasty, ca. 1570-1650, “were prompted by economic distress rather than by religious or ethnic

\footnotetext{
${ }^{18}$ Zvi Ben-Dor Benite, The Dao of Muhammad: A Cultural History of Muslims in Late Imperial China (Cambridge, MA: Harvard University Asia Center, 2005).

${ }^{19}$ Lipman, Familiar Strangers: A History of Muslims in Northwest China, 72-85.

${ }^{20}$ James D. Frankel, Rectifying God's Name: Liu Zhi's Confucian Translation of Monotheism and Islamic Law (Honolulu: University of Hawaii Press, 2011).

${ }^{21}$ Jonathan Lipman, Islamic Thought in China: Sino-Muslim Intellectual Evolution from the 17h to the 21st Century (Edinburgh: Edinburgh University Press, 2016); Roberta Tontoni, Muslim Sanzijing: Shifts and Continuities in the Definition of Islam in China (Leiden: Brill, 2016).

22 James D. Frankel, "Chinese-Islamic connections: an historical and contemporary overview," Journal of Muslim Minority Affairs 36, no. 4 (2016): 569-583, at 573.
} 
discrimination". ${ }^{23}$ On the other hand, contemporary observers and modern commentators have often seen these and similar revolts as a sign of Muslim disloyalty. This could have serious consequences for the rebels in case of defeat. For example, after uprisings in the second half of the nineteenth century, many Sino-Muslims were displaced westwards from their erstwhile core in Shaanxi, with some of them migrating as far as the Russian Empire. ${ }^{24}$

There are many alleged instances of Hui disloyalty. Hui communities were often forced to take sides in power struggles, sometimes with deleterious consequences. For example, there are bitter memories of Hui uprisings and their suppression during the republican era. The suppression of a Muslim uprising in Shaanxi is still remembered by the progeny of the victims. ${ }^{25}$ During the Civil War, the Hui communities of Qinghai and Gansu were staunchly anticommunist and, as a consequence, their loyalty is seen as doubtful to the present day. ${ }^{26} \mathrm{Re}-$ portedly, the last attempt by Hui to erect a Muslim emirate was defeated as late as $1958 .{ }^{27}$

\footnotetext{
${ }^{23}$ Morris Rossabi, "Muslim and Central Asian revolts," in From Ming to Ch'ing: Conquest, Region, and Continuity in Seventeenth Century China, ed. Jonathan D. Spence and John E. Wills (New Haven: Yale University Press, 1979), 167-199.

${ }^{24}$ Svetlana Rimsky-Korsakoff Dyer, Soviet Dungans in 1985: Birthdays, Weddings, Funerals and Kolkhoz Life (Taipei: Center for Chinese Studies, 1991).

${ }^{25}$ Maris Gillette, "Violence, the state, and a Chinese Muslim ritual remembrance," Journal of Asian Studies 67, no. 3 (2008): 1011-1037.

${ }^{26}$ Susette Cooke, "Surviving state and society in Northwest China: the Hui experience in Qinghai Province under the PRC," Journal of Muslim Minority Affairs 28, no. 3 (2008): 401-420.

${ }^{27}$ Raphael Israeli, Islam in China: Religion, Ethnicity, Culture, and Politics (Lanham, MD: Lexington Books, 2002), 199. On a similar attempt by Uyghurs in the mid-1950s, see Michael Dillon, Xinjiang: China's Muslim Far Northwest (London: Routledge, 2004), 52-55.
} 


\section{The Uyghurs}

The Uyghurs offer a remarkable contrast. Most Muslims of Xinjiang are of Turkic stock and came into the fold of the Empire only with the Qing expansion of the eighteenth century. Like other Turkic minorities in Xinjiang such as the Kazaks and the Kirgiz, the Uyghurs have jealously guarded their linguistic and cultural traits of distinction from the Han, as well as Sinicized Muslims such as the Hui. They have gained notoriety for their recalcitrance.

Especially during the Empire's period of weakness in the nineteenth century and the turmoil of the republican era in the first half of the twentieth century, there were numerous uprisings in Xinjiang. Islamist and jihadist elements were quite prominent during the reign of the Turkic usurper Yaqub Beg during the 1860s and 1870s and under the ill-fated Turkic Islamic Republic of Eastern Turkestan (TIRET), lasting from 1933 to 1934. Another East Turkestan Republic (ETR), which was backed by the Soviet Union and lasted from 1944 to 1949, was less overtly religious than its predecessors. ${ }^{28}$ Today, Uyghur religious nationalists ritualistically remember all of these uprisings, and especially the two East Turkestan republics.

If Hui loyalty to China is sometimes questioned, Uyghur disloyalty is mostly taken for granted. The general view is that the Hui rebellions, despite their violent character, mostly represented local power struggles rather than head-on collisions with imperial authority. ${ }^{29}$ The

\footnotetext{
${ }^{28}$ Andrew D. W. Forbes, Warlords and Muslims in Chinese Central Asia: A Political History of Republican Sinkiang 1911-1949 (Cambridge: Cambridge University Press, 1986); Linda Benson, The Ili Rebellion: The Moslem Challenge to Chinese Authority in Xingjiang, 1944-1949 (Armonk, NY: M.E. Sharpe, 1990); Hodong Kim, Holy War in China: The Muslim Rebellion and State in Chinese Central Asia, 1864-1877 (Stanford, CA: Stanford University Press, 2004).

${ }^{29}$ Lipman, Familiar Strangers: A History of Muslims in Northwest China.
} 
Turkic insurgencies in Xinjiang, by contrast, are seen as radically opposed to Chinese rule. Although the Hui were at least as often engaged in uprisings as the Uyghurs, conventional wisdom has it that Uyghur uprisings were more likely to have a religious element.

In the Uyghur case, history is habitually invoked to make sense of ongoing intercommunal problems. In the case of the Hui, by contrast, both sides tend to deemphasize a seditious past and emphasize the loyalty of the Hui to China and the Chinese Communist Party. It bears emphasis that, occasionally, the religious element in Hui uprisings was rather pronounced, most notably in an insurgency that took place in Yunnan and lasted from 1856 to 1873, culminating in the attempt of the rebels to erect a separate Muslim state under "Sultan Suleiman.” ${ }^{30}$ Regardless, the confrontational aspects in the history of Han-Uyghur relations are remembered far more vividly than those in the history of Han-Hui relations.

\section{Legacies of the past}

All of this amounts to a socio-spatial hierarchy in which the Hui are regarded as closer to the Han civilizational center than the Uyghurs. Following a similar logic, distinctions are made between sub-sections of either minority. Despite an emphasis on Hui loyalty across the board, there remains a residual awareness of the rebellious history of the Hui in the northwest. The urban Hui of China's coastal region are seen as most acculturated and thus closest to the Han civilizational core, followed by the religiously more traditionalist Hui of Ningxia in the west, followed by the previously rebellious Hui of Qinghai province. Similarly, Uyghurs from re-

\footnotetext{
${ }^{30}$ David G. Atwill, The Chinese Sultanate: Islam, Ethnicity, and the Panthay Rebellion in Southwest China, 1856-1873 (Stanford, CA: Stanford University Press, 2005).
} 
mote oases in southwestern Xinjiang are seen as more rebellious and culturally more alien than Uyghurs from the more accessible northeast of the same region. ${ }^{31}$

Such distinctions are deeply anchored in Chinese collective consciousness and based on an old history. They remain discernible as a Han-centric socio-spatial hierarchy radiating out from the old imperial heartland of the east and southeast to the multiethnic provinces and regions in the west and northwest. As one scholar puts it: "The popular conception among foreign observers is that Xinjiang is tightly controlled, and 'inner China' is more loosely governed; in reality, however, there is a gradation. While Xinjiang remains much more strictly controlled than elsewhere in Northwest China, affairs in Gansu and Qinghai, including economic matters, are also subject to considerable oversight by the government.”32

Through the erstwhile imperial strategy of "using barbarians to control barbarians," such practices have also left their mark on Uyghur-Hui relations. Under the Qing and during the subsequent warlord period, the unstable borderland of Xinjiang was deliberately garrisoned with Sino-Muslims, now called Hui, to control and repress Central Asian Muslim populations such as the Uyghurs. ${ }^{33}$ Sino-Muslims were used to control Turkic Muslims such as the Uyghurs, and this has led to enduring animosities between the communities. As late as the 1930s,

\footnotetext{
${ }^{31}$ Justin Jon Rudelson, Oasis Identities: Uyghur Nationalism Along China's Silk Road (New York: Columbia University Press, 1997); Ildikó Bellér-Hann, "The “Gateway to the Western Regions”: state-society relations and differentiating Uighur marginality in China’s northwest," ed. Zsombor Rajkai and Ildikó Bellér-Hann (Wiesbaden: Harrassowitz, 2012), 203-222.

${ }^{32}$ Matthew S. Erie, China and Islam: The Prophet, the Party, and Law (New York: Cambridge University Press, 2016), 268.

${ }^{33}$ Kim, Holy War in China: The Muslim Rebellion and State in Chinese Central Asia, 1864-1877.
} 
the Kuomintang used Hui militias as proxies to suppress the East Turkestan Republic. ${ }^{34}$ In the twenty-first century, Turkic Muslims continue to see the Hui as civilizational agents, or proxies, of the Han. As Lipman puts it, Turkic Muslims view the Hui “as ‘them’ by culture and language rather than 'us’ by religion.”35 The Muslim Kazaks also play a role as strategic allies of the Chinese state in its quest to restrain and control Xinjiang's Uyghurs. ${ }^{36}$

Let me end this section on a quick terminological note. Despite an official discourse that either trivializes Muslim identity as ethnic or paints an undifferentiated picture of religious radicalism and Islamic extremism, religion and ethnicity are hardly separable among China’s Muslims. Central Asian minorities such as the Uyghurs and the Kazaks have for a long time defined themselves vis-à-vis the Chinese state and society by their religion as much as by their ethnicity. Uyghur mobilization is therefore best characterized as "religious nationalist" or "ethnoreligious." ${ }^{37}$ Although for somewhat different reasons, the same applies to the Hui who are distinguished from their typically Han neighbors primarily by their Muslim religion but whom the Chinese state chose to classify as an ethnic group in the 1950 s. $^{38}$

\footnotetext{
${ }^{34}$ Forbes, Warlords and Muslims in Chinese Central Asia: A Political History of Republican Sinkiang 19111949.

35 Jonathan N. Lipman, "White hats, oil cakes, and common blood: the Hui in the contemporary Chinese state," in Governing China's Multiethnic Frontiers, ed. Morris Rossabi (Seattle: University of Washington Press, 2004), $19-52,51$.

${ }^{36}$ Benson and Svanberg, China's Last Nomads: The History and Culture of China's Kazaks.

${ }^{37}$ Peter van der Veer, "Nationalism and religion," in The Oxford Handbook of the History of Nationalism, ed. John Breuilli (Oxford: Oxford University Press, 2013), 655-671.

${ }^{38}$ Colin Mackerras, "Some issues of ethnic and religious identity among China's Islamic peoples," Asian Ethnicity 6, no. 1 (2005): 3-18; Gladney, Muslim Chinese: Ethnic Nationalism in the People's Republic; Gladney, "Islam in China: state policing and identity politics."
} 


\section{Political Relations}

In line with the socio-spatial hierarchy, the Chinese state applies a bespoke mix of controls, preferential policies, and negative sanctions to the Hui and the Uyghurs. As we will see, the balance of preferential policies and negative sanctions clearly favors the Hui. Nevertheless, both cases depart from a common template. Let us discuss the template first, and then assess the systematic variation between the specific policies applied to either group.

In terms of controls, Beijing tries to manage Muslim activities by placing them under the umbrella of a "patriotic religious association," the China Islamic Association. The Islamic Association is an official state-directed apex body, headquartered in Beijing. Among its duties, it includes missions such as to "support the Chinese Communist Party’s leadership”, “adapt Islam to socialist society", "hold high the banner of patriotism, unity, and progress", "refute the fallacies of religious extremism", "establish and improve the internal management rules and regulations of Islam”, and "train Islamic teaching personnel”. Crucially, the Islamic Association is mandated to "strengthen the organization of the pilgrimage" to Mecca (hajj) and oversees the education, certification, and professional practices of Muslim clerics. ${ }^{39}$

Every aspirant imam needs to pass an interview conducted by a branch of the Islamic Association. Most graduates from an officially approved seminary can proceed straight to the interview, without exam. They can take this shortcut because the curriculum of their seminary was established by the Islamic Association, and faculty members are government employees.

\footnotetext{
${ }^{39}$ Translated from “Zhongguo yisilanjiaoxiehui zhangcheng (Charter of the China Islamic Association),” published in Zhongguo musilin (Chinese Muslim) 193, n. 5 (2011): 24-26 and reproduced on the IAC website, www.chinaislam.net.cn.
} 
Those who have received their education from another entity such as a registered mosque, must pass a written exam in addition to the interview. Either way, Muslim clerics remain subject to the authority of the China Islamic Association, together with the local Bureau of the State Administration of Religious Affairs (SARA) and Party organs such as the United Front Work Department (UFWD, an organ of the Communist Party’s central committee) ${ }^{40}$

Such controls are supplemented by preferential policies. Muslims and other minority groups have been exempt from the one-child policy. Minority people have been free to have at least two children (more than two in rural areas), and they benefit from easier access to universities. ${ }^{41}$ There are other policies of affirmative action, such as minority quotas for employment in the public sector. Preferential policies, in turn, are counterbalanced by negative sanctions such as the suppression of "illegal religious activities". To provide another example, members of the Chinese Communist Party are not allowed to openly practice religion. ${ }^{42}$

Participation in the hajj to Mecca is a good indicator for assessing the balance of preferential policies as opposed to negative sanctions for different Muslim communities. Chinese authorities are notoriously wary of cultural and religious influences from the Middle East, and especially from Saudi Arabia, which is why they tightly control participation in the hajj. On the

${ }^{40}$ Chris Hann, "Laiklik and legitimation in rural eastern Xinjiang," in Varieties of Secularism in Asia: Anthropological Explorations in Religion, Politics and the Spiritual, ed. Nils Bubandt and Martin van Beek (London: Routledge, 2012), 121-241; Erie, China and Islam: The Prophet, the Party, and Law, 81-81, 187, 311315.

${ }^{41}$ Reza Hasmath, "The education of ethnic minorities in Beijing," Ethnic and Racial Studies 34, no. 11 (2011): 1835-1854.

${ }^{42}$ In Chinese constitutional doctrine and political practice, religious freedom is largely understood as the freedom of non-religious people from religious indoctrination. See Chinese Constitution, Art. 36; Beatrice Leung, "China's religious freedom policy: the art of managing religious activity," China Quarterly 184(2005): $894-913$. 
one hand, pilgrimage numbers have been increasing ever since the late 1970s. On the other hand, there have been occasional backlashes against the hajj, as happened in 1990 when Uyghur exiles where seen as “subverting” pilgrims from Xinjiang, and again in 1996 when there were official complaints that pilgrims had returned to China "dressed like Arabs."

According to a report by the U.S. Commission on International Religious Freedom, in the autumn of 2012 approximately 13,800 Muslims from China participated in the hajj, "flown on 41 specially arranged Hajj charter flights, although this number included Islamic Association and security officials sent to monitor Muslim citizens and prevent unauthorized pilgrimages. Uighur Muslims separately reported difficulties taking part in state-sanctioned Hajj travel due to the inability to obtain travel documents in a timely manner, difficulties in meeting criteria required for participation in the official Hajj program run by the China Islamic Association, and quotas on the number of travelers from the country imposed by Saudi Arabia. The government took measures to limit the ability of Uighur Muslims to make private Hajj pilgrimages outside of the government-organized program.”44

In 2015, there were 14,528 participants on the Chinese hajj delegation. ${ }^{45}$ This included 3,093 from Xinjiang and 2,814 from Ningxia. ${ }^{46}$ Since almost all Ningxia Muslims are Hui, this

\footnotetext{
${ }^{43}$ Dillon, Xinjiang: China's Muslim Far Northwest, 66, 90.

${ }^{44}$ U.S. Commission on International Religious Freedom, Annual Report 2012 (Washington, DC: U.S. Commission on International Religious Freedom, 2012).

45 State Administration for Religious Affairs, "2015 Chaojingongzuozongtuan ping’an fanhui guonei, jinnian chaojinzuzhigongzuo yuanmanjieshu (2015 Hajj mission safely returned and the organization of Hajj in 2015 finished successfully)," 21 October 2015.

${ }^{46}$ Xinjiang Ethnic Affairs Commission, "Xinjiang youzuzhi chaojingongzuo wenbutuijin (Organized Hajj work in Xinjiang is moving forward steadily," 3 July 2015; State Administration for Religious Affairs,
} 
translates into one pilgrim in every 828 Hui from Ningxia. ${ }^{47}$ Under the hypothetical assumption that all pilgrims from Xinjiang were Uyghurs, there would be one pilgrim in every 3,473 Uyghurs. ${ }^{48}$ Since there are other Muslim minorities in Xinjiang, there must be something like one pilgrim per 4,000 Uyghurs from Xinjiang. This means that Hui from Ningxia are between four and five times as likely to be on a hajj delegation as Uyghurs from Xinjiang. The disparity puts concrete numbers to the more general pattern that Hui Muslims have easier access to privileges and are less exposed to restrictions than their Uyghur coreligionists.

Another way to assess this pattern is a comparison between the relevant regulations on religious affairs in Ningxia and Xinjiang. The most striking difference is that regulations in Xinjiang are much stricter and more detailed than in Ningxia. Regulations for Xinjiang emphasize terms that are hardly mentioned in regulations for Ningxia, such as "national unity", "social stability”, “public order”, “patriotism”, “prevention of religious extremism”, “violence”, “terrorism”, and “secessionism”. For a synopsis of other key differences, see Table 2.

\begin{tabular}{|l|l|l|}
\cline { 2 - 3 } \multicolumn{1}{c|}{} & Ningxia & Xinjiang \\
\hline $\begin{array}{l}\text { Outlawed religious } \\
\text { activities }\end{array}$ & $\begin{array}{l}\text { Not specified at the regional } \\
\text { level but only in some cities } \\
\text { and counties where Hui ac- } \\
\text { count for a large proportion } \\
\text { of the population (e.g. } \\
\text { Wuzhong city, Xiji county) }\end{array}$ & $\begin{array}{l}\text { Binding region-wide list of 26 illegal } \\
\text { religious activities, including religious } \\
\text { meetings at home, fasting to disrupt } \\
\text { public life, transmission of the call to } \\
\text { prayer by loudspeaker, foreign contacts }\end{array}$ \\
\hline $\begin{array}{l}\text { Reporting duties } \\
\text { for illegal religious } \\
\text { activities }\end{array}$ & $\begin{array}{l}\text { To the regional department of } \\
\text { the State Administration of } \\
\text { Religious Affairs (SARA) }\end{array}$ & $\begin{array}{l}\text { Not only to the regional department of } \\
\text { SARA but also to police and public } \\
\text { security departments }\end{array}$ \\
\hline
\end{tabular}

\footnotetext{
"Ningxiayinhang huozhun shidian kaiban yisilan yinhangyewu (Hajj work in Ningxia Hui Autonomous Region has been well prepared)," 31 August 2015.

${ }^{47}$ Calculation based on the latest population data of 2,328,975 Hui in Ningxia in 2013.

${ }^{48}$ Calculation based on the latest population data of 10,744,100 Uyghurs in Xinjiang in 2013.
} 


\begin{tabular}{|l|l|l|}
\hline $\begin{array}{l}\text { Indoctrination of } \\
\text { religious personnel }\end{array}$ & Hardly addressed & $\begin{array}{l}\text { SARA departments at county level or- } \\
\text { ganize training courses }\end{array}$ \\
\hline Censorship & $\begin{array}{l}\text { Addressed only in generic } \\
\text { terms, establishing the re- } \\
\text { gional department of SARA } \\
\text { as the competent agency }\end{array}$ & $\begin{array}{l}\text { Detailed rules for the censorship of re- } \\
\text { ligious publications. No audio or video } \\
\text { broadcasting of “illegal preaching." } \\
\text { Ban on the use of digital media to } \\
\text { spread materials lacking approval. }\end{array}$ \\
\hline Overseas support & Hardly addressed & $\begin{array}{l}\text { Prohibition of overseas funding for re- } \\
\text { ligious endowments and personnel. } \\
\text { Prohibition of other overseas support. }\end{array}$ \\
\hline
\end{tabular}

Table 2: Key differences between religious regulations in Ningxia and Xinjiang ${ }^{49}$

\section{State-Hui relations}

The Chinese state has a relaxed attitude when it comes to religious controls of the Hui, granting the latter a level of toleration that would be inconceivable for Turkic Muslim minorities such as the Uyghurs. For example, it is seen as unacceptable for a Uyghur party member to practice "religious belief” because of the official emphasis on atheism. In the case of a Hui, Mosque attendance might be classified as an acceptable form of "ethnic customs.”

The Hui are afforded many privileges such as new mosques even in small communities, minority schools in large urban centers, relatively free commerce in religious publications and

\footnotetext{
${ }^{49}$ Sources (viewed on 15 January 2016): Xinjiangweiwu'erzizhiqu zongjiaoshiwu tiaoli (Regulations of the Xinjiang Uyghur Autonomous Region on Religious Affairs), implemented since 1 January 2015, http://www.pkulaw.cn/fulltext_form.aspx?Db=lar\&Gid=17713696; Ningxiahuizuzizhiqu zongjiaoshiwu ruogan guiding (Regulations of the Ningxia Hui Autonomous Region on Religious Affairs), implemented since 1 August 2013, http://www.pkulaw.cn/fulltext_form.aspx?Db=lar\&Gid=17529965; Xinjiang Government, Guanyu jieding feifa zongjiaohuodong de yijian (Opinions on the Definition of Illegal Religious Activities), updated version implemented since 2011,
}

http://120.71.224.92:8090/indexpub/010614874/article.jsp?identifier=010614874/2013-00005. 
cultural artifacts, and comparatively easy access to participation in the hajj. ${ }^{50}$ Whereas majority schools in China are coeducational, Muslim minority institutions are sometimes allowed to be girls-only. ${ }^{51}$ The state even tolerates mosque-affiliated nurseries and schools where Arabic, including Quran education, is at the center of the curriculum. ${ }^{52}$

To be sure, there are limits to the effectiveness of preferential policies. Few graduates from Muslim-only schools are competitive in the national entrance examination for Chinese universities, although some make their way to institutions of higher learning in Muslim countries like Malaysia, Pakistan, or the Middle East. ${ }^{53}$ While Hui Muslims are overrepresented at the

\footnotetext{
${ }^{50}$ Cooke, "Surviving state and society in Northwest China: the Hui experience in Qinghai Province under the PRC," 415; Andrew Jacobs, "Light government touch lets China's Hui practice Islam in the open," New York Times, 2 February 2016.

${ }^{51}$ Rosey Wang Ma, "The silent march: unveiling the gentle power behind the consolidation of Islam in the Western region of China," World Journal of Islamic History and Civilization 2, no. 2 (2012): 108-115. Apparently, the underlying rationale on the part of Hui Muslims is to educate females in Islam so that they can impart the religion to their children while boys are sent to mainstream schools in preparation for a professional career. This seems related to a longstanding Hui tradition of passing on religious knowledge and religious practices through female education and women's mosques. See Maria Jaschok and Jingjun Shui, The History of Women's Mosques in Chinese Islam: A Mosque of Their Own (Richmond, UK: Curzon, 2000).

${ }^{52}$ Subsequent to a terrorist attack in Kunming, Chinese authorities have started to roll this back in Yunnan province through an edict promulgated by the government of Yunnan on 23 September 2014 and entitled "Guanyu qieshijiaqiang ayuxuexiao he yisilanjiao jingwenxuexiao(ban) guifanguanligongzuo yijian (Opinions on the promotion of management of Arabic language schools and Islamic institutes)."

${ }^{53} \mathrm{Ma}$, "The silent march: unveiling the gentle power behind the consolidation of Islam in the Western region of China."
} 
level of highly symbolic although not necessarily influential senior official posts, they tend to be underrepresented at the level of the bureaucratic rank and file. ${ }^{54}$

For the Hui, reconciling their loyalty to China with their allegiance to the Muslim ummah remains a tightrope walk. This became clear in May 1989, at the time of the protests on Tiananmen Square. While Han students were protesting against the government, Hui Muslims were rallying to petition the government for a ban on a book denigrating Muslim sexual mores. People shouted “Allahu Akbar” alongside slogans like "Uphold the Constitution” and “Love our Country, Love our Religion”. The rallies were in protest against a book entitled Sexual Customs, characterizing the mores of Muslims in a way seen as offensive and blasphemous. On some banners, the book was called "The Satanic Verses of China”, although Chinese Muslims did not otherwise participate in the worldwide protests against Salman Rushdie's controversial novel. ${ }^{55}$ Interestingly, the Chinese government was responsive to the protesters and outlawed the book. ${ }^{56}$

The friendly attitude of the Chinese state towards the Hui is in line with the imperial tradition of seeing the Hui as affiliates of the Han rather than as barbarians, as Hua rather than $\mathrm{Yi}$ (or

\footnotetext{
${ }^{54}$ Dillon, China's Muslim Hui Community: Migration, Settlement and Sects, 170. Although Dillon's observation dates back to 1998, it is probably still valid.

${ }^{55}$ Dru C. Gladney, "Salman Rushdie in China: religion, ethnicity, and state definition in the People’s Republic," in Asian Visions of Authority: Religion and Modern States of East and Southeast Asia, ed. Charles F. Keyes, Laurel Kendall, and Helen Hardacre (Honolulu: University of Hawaii Press, 1994), 255-278; James D. Frankel, "'Apoliticization': one facet of Chinese Islam," Journal of Muslim Minority Affairs 28, no. 3 (2008): 421-434.

${ }^{56}$ While the Hui were allowed to hold rallies in various cities, and while they were allowed to burn copies on the main square of Lanzhou, there was a crackdown on Uyghur protestors in Urumqi denouncing the same book. See Gladney, "Salman Rushdie in China: religion, ethnicity, and state definition in the People’s Republic."
} 
as Min rather than Fan). ${ }^{57}$ Under this tradition, the Hui were considered Sinicized and thus governable, at least when compared to the outer barbarians. Even today, the tradition is very much alive. For example, an influential history book begins with the patronizing statement that the Hui are "relatively economically and culturally advanced." 58

Nevertheless, Han-Hui relations are not always as harmonious as officially proclaimed. In a 1990 standoff in Yunnan, “[v]ehicles filled with explosives, manned by volunteers for martyrdom, were placed in position to blow up the police stations, if it were deemed necessary”, and "the men wrote Arabic prayers on white cloths, wrapped themselves in these shrouds, seized their weapons, and prepared to die.”59 The incident was defused with careful deescalation tactics, and most other cases of Hui protest are less dramatic and about local grievances rather than head-on collisions. Yet, there are flares of Hui "rebelliousness.”

Perhaps more worryingly from the perspective of the Chinese state and Party, in recent years there has been Islamic revivalism among small but growing segments of Hui society in northwestern China, including an interest in the conversion of non-Muslims to Islam and receptiveness to transnational Islamist influences like Salafism and the Tablighi Jamaat. ${ }^{60}$

\footnotetext{
${ }^{57}$ Cooke, "Surviving state and society in Northwest China: the Hui experience in Qinghai Province under the PRC," 405.

${ }^{58}$ Authors' Collective, Huizu jianshi (Brief History of the Hui Nationality) (Beijing: Ethnic Publishing House, 2009).

${ }^{59}$ Lipman, "White hats, oil cakes, and common blood: the Hui in the contemporary Chinese state," 19-20.

${ }^{60}$ Mohammed Turki A Al-Sudairi, "Adhering to the ways of our western brothers: tracing Saudi influences on the development of Hui Salafism in China," Sociology of Islam 4, no. 1 (2016): 27-58; Alexander Blair Stewart, Chinese Muslims and the Global Ummah: Islamic Revival and Ethnic Identity among the Hui of Qinghai
} Province (London: Routledge, 2017). 


\section{State-Uyghur relations}

In the Uyghur case, the informal socio-spatial hierarchy acts like a trap for both sides. When Beijing applies to Uyghurs the accommodative policies that it applies to other minorities, Uyghurs hardly embrace them but rather see them as a ruse to undermine their identity. When Beijing then falls back on a more repressive pattern of controls, then the Uyghur response is even more negative given the history of communal resentment and humiliation.

Ever since the onset of communist rule, the state has frowned upon Uyghurs practicing Islam, but some restrictions were relaxed after the excesses of the Cultural Revolution. For example, Chinese authorities silently tolerated the participation of public officials and party members in religious ceremonies. Similarly, they tolerated the presence of minors under eighteen in mosques despite a formal ban. However, from the viewpoint of state officials this lead to the counterproductive outcome of greater Uyghur assertiveness. ${ }^{61}$ Therefore, after a rather liberal period in the reform era of the 1980s, Beijing returned to a more repressive policy against Uyghur religious nationalism. ${ }^{62}$ In this context, there is often an excessive emphasis on the Salafi-jihadist threat at the expense of ethno-nationalist motivations. ${ }^{63}$

\footnotetext{
${ }^{61}$ Graham E. Fuller and Jonathan N. Lipman, "Islam in Xinjiang," in Xinjiang: China's Muslim Borderland, ed. S. Frederick Starr (Armonk, NY: M.E. Sharpe, 2004), 320-352.

${ }^{62}$ Edmund Waite, "The impact of the state on Islam amongst the Uyghurs: religious knowledge and authority in the Kashgar Oasis," Central Asian Survey 25, no. 3 (2006): 251-265.

${ }^{63}$ Kendrick T. Kuo, "Revisiting the Salafi-jihadist threat in Xinjiang," Journal of Muslim Minority Affairs 32, no. 4 (2012): 528-544.
} 
The backlash started after an armed uprising at the Uyghur town of Baren in April $1990 .{ }^{64}$ With the "Strike Hard" campaign of 1996 and a subsequent uprising in Yining/Ghulja in 1997, Chinese authorities further hardened their approach. ${ }^{65}$ The rules against the participation of party members in religious ceremonies and the presence of minors in mosques were tightened again (enforcement is less strict in rural areas). Underground religious schools were closed, and the exchange of preachers between mosques was restricted. ${ }^{66}$

The backlash has further intensified since 9/11 and sometimes takes extreme forms. ${ }^{67}$ After the 2009 Urumqi riots, Uyghur truck drivers were denied licenses for driving oil tankers because they were seen as potential suicide attackers. ${ }^{68}$ In 2013-2014, there was another wave of Uyghur terrorist activity, including a suicide attack on Tiananmen Square, a mass stabbing in Kunming, and a bomb attack in Urumqi timed to coincide with a visit by President Xi Jinping. This was followed by further sanctions disrupting public life and religiosity in Xinjiang, including an intensified de-veiling campaign targeting Uyghur women. ${ }^{69}$ The situation

\footnotetext{
${ }^{64}$ Bovingdon, The Uyghurs: Strangers in Their Own Land, 120-121; Dillon, Xinjiang: China's Muslim Far Northwest, 62-65.

${ }^{65}$ CCP, "Chinese Communist Party Central Committee Document No. 7: Record of the Meeting of the Standing Committee of the Politburo of the Chinese Communist Party Concerning the Maintenance of Stability in Xinjiang," Human Rights Watch 10, no. 1 [C] (1996): 10-14; Dillon, Xinjiang: China's Muslim Far Northwest, 84-98.

${ }^{66}$ Fuller and Lipman, "Islam in Xinjiang."

${ }^{67}$ Martin I. Wayne, China's War on Terrorism: Counter-Insurgency, Politics and Internal Security (London: Routledge, 2008).

${ }^{68}$ Andrew Jacobs, "Uyghurs in China say bias is growing," New York Times, 8 October 2013.

${ }^{69}$ Colin Mackerras, "Xinjiang in 2013: problems and prospects," Asian Ethnicity 15, no. 2 (2014): 247-250;

Andrew Jacobs, "Nearly 100 reported killed in week of unrest in China," New York Times, 3 August 2014;
} 
has hardly calmed down since. In 2015, an attack on a coal mine ended in about 50 casualties. ${ }^{70} 2016$ saw a suicide bombing at the Chinese embassy in Kyrgyzstan and an armed attack at a Communist Party Office in Xinjiang killing 5 people. ${ }^{71}$ Chinese authorities have remained on high alert, confiscating numerous passports and adopting strict internet controls. ${ }^{72}$

At the same time, the Chinese authorities continue to deploy preferential policies and "affirmative action.” For example, the offspring of Uyghur parents enjoy preferential access to university, with a significantly lower bar at university entrance exams. Like other minorities, Uyghurs have access to a dedicated Minzu University of China, located in Beijing. ${ }^{73}$ The Chinese Communist Party even runs a highly ambitious (re)education program whereby around 10,000 Uyghur children, predominantly from traditionalist southern Xinjiang, are sent to eastern China every year to imbibe the "Zonghua minzu identity" in the "Xinjiang Class”—only to embrace a reconstructed Uyghur Muslim identity after graduation. ${ }^{74}$

James Leibold and Timothy A. Grose, "Veiling in Xinjiang: the political and societal struggle to define Uyghur female adornment," China Journal, no. 76 (2016): 78-102.

${ }^{70}$ Javier C. Hernández, "China acknowledges killing 28 people; accuses them of role in mine attack," New York Times, 20 November 2015.

${ }^{71}$ Ivan Nechepurenko, "Bomber strikes Chinese embassy in Kyrgyzstan," New York Times, 31 August 2016; Javier C. Hernández, "China says 5 killed in attack at Communist Party office in Xinjiang," New York Times, 30 December 2016.

72 Edward Wong, "China police pulls passports in some parts of Xinjiang," New York Times, 2 December 2016; Edward Wong, "Xinjiang, tense Chinese region, adopts strict Internet controls," New York Times, 10 December 2016.

${ }^{73}$ Hasmath, "The education of ethnic minorities in Beijing," 1845-1847.

${ }^{74}$ Timothy A. Grose, "(Re)embracing Islam in Neidi: the 'Xinjiang Class' and the dynamics of Uyghur ethnonational identity," Journal of Contemporary China 24, no. 91 (2015): 101-118. 
Until the mid-2000s, affirmative action was frustrated by the fact that most Uyghurs sent their offspring to minority schools where instruction was in the Uyghur language. Ethnographic studies suggest that they believed doing otherwise might have compromised the cultural and religious identity of their offspring. Perhaps more seriously for the children involved, Uyghurs schooled in Mandarin (minkaohan) suffered from discrimination and resentment in both Uyghur and Han society. ${ }^{75}$ Since the 2000s, the Xinjiang government has counteracted this tendency by vigorously promoting "bilingual” education. Bilingualism is understood as education in Mandarin supplemented by the mother tongue.

It remains to be seen whether and to what extent this translates into greater university enrollment for Uyghurs. It stands to reason, however, that greater proficiency in Mandarin should enable more Uyghur high school graduates to benefit from positive discrimination at universities, where proficiency in Mandarin is a requirement. ${ }^{76}$ Indeed, as long as few Uyghurs graduate from university, no conspiracy theory is needed to explain why they remain underrepresented in the public sector, despite an official policy of affirmative action. ${ }^{77}$

\footnotetext{
${ }^{75}$ Jennifer Taynen, "Interpreters, arbiters or outsiders: the role of the Min kao Han in Xinjiang society," Journal of Muslim Minority Affairs 26, no. 1 (2006): 45-62.

${ }^{76}$ Rong Ma, "Xinjiang minzujiaoyu de fazhan yu shuangyujiaoyu de shijian (Minority education and the practice of bilingual teaching in Xinjiang)," Beijingdaxue jiaoyupinglun (Peking University Education Review) 6, no. 2 (2008): 2-41.

${ }^{77}$ Linda Benson, "Education and social mobility among minority populations in Xinjiang," in Xinjiang: China's Muslim Borderland, ed. S. Frederick Starr (Armonk, NY: M.E. Sharpe, 2004), 190-215; Cheng Li, "Ethnic minority elites in China's party-state leadership: an empirical assessment," China Leadership Monitor 25(2005); Barry Sautman, "Preferential policies for ethnic minorities in China: the case of Xinjiang," Nationalism and Ethnic Politics 4, no. 1 (2005): 86-118; Bovingdon, The Uyghurs: Strangers in Their Own Land, 63-64. While there is affirmative action at the level of the bureaucratic rank-and-file, at the highest level there is a genuine
} 
There are many religious restrictions specific to Xinjiang. The call to prayer must not be transmitted by loudspeaker (see Table 2), a rule that does not apply elsewhere. Uyghur students must not be caught performing their daily prayers or wearing religious garb. ${ }^{78}$ Chinese authorities have been reluctant to issue passports and other travel documents to Uyghurs, and particularly to Uyghur students seeking permission to study abroad, in order to prevent them from exposure to extreme nationalist and/or Islamist ideas. ${ }^{79}$ Home-based and otherwise unregistered religious activities are not only considered illegal but also severely persecuted. ${ }^{80}$

Uyghur clerics are state-appointed and must be graduates from the Xinjiang Islamic Religion Institute in Urumqi, which monopolizes the training of "patriotic clerics." ${ }^{81}$ While a similar policy also applies to other Muslims like the Hui and the Kazaks, many Uyghurs are not willing to tolerate the submission of their clerics to Chinese authorities. This leaves the clerics between a rock and a hard place. When they strive to remain independent, then their profile

reluctance of the Chinese state to surrender control to minority representatives. Thus, the governor of Xinjiang and the president of the regional assembly are typically Uyghurs, but de-facto power is wielded by the secretary of the regional committee of the Communist Party, who is invariably a Han. See Enze Han, Contestation and Adaptation: The Politics of National Identity in China (Oxford: Oxford University Press, 2013), 42.

${ }^{78}$ Fuller and Lipman, "Islam in Xinjiang."; Bovingdon, The Uyghurs: Strangers in Their Own Land, 65-72; Michael E. Clarke, Xinjiang and China's Rise in Central Asia: A History (London: Routledge, 2011), 129-140. ${ }^{79}$ Smith Finley, The Art of Symbolic Resistance: Uyghur Identities and Uyghur-Han Relations in Contemporary Xinjiang, 252.

${ }^{80}$ U.S. Commission on International Religious Freedom, 2016 Annual Report (Washington, DC: U.S. Commission on International Religious Freedom, 2016).

${ }^{81}$ Yitzhak Shichor, "Blow up: internal and external challenges of Uyghur separatism and Islamic radicalism to Chinese rule in Xinjiang," Asian Affairs 32, no. 2 (2005): 119-135, 128. Small neighborhood mosques are sometimes allowed to have religious leaders outside the public payroll. Precisely for this reason, state informers routinely attend their sermons and the police monitor their activities. 
as community leaders gets them in trouble with Chinese authorities. ${ }^{82}$ When they are submissive to the authorities, however, they may lose followers or even face assassination. ${ }^{83}$

While the restrictive policies in Xinjiang appear objectionable from a western-liberal perspective, Chinese authorities do have reason to be on their guard. Even scholars sympathetic with Uyghur grievances acknowledge a palpable element of ethnoreligious radicalism in Uyghur society. ${ }^{84}$ Western academics visiting Xinjiang found Islamists claiming that "nonMuslim rule over Muslims can never be legitimate and that Uyghurs must therefore struggle for independence and the formation of a Muslim state". They heard "oblique references to underground religious schools” and rumors of support for Uyghur resistance emanating from Central Asia, Pakistan and, until 2001, Taliban-controlled Afghanistan. ${ }^{85}$

This places Chinese authorities in a difficult position. On the one hand, the Communist Party is desperate to avoid a repetition of the situation in the 1990s when the Xinjiang Daily wrote: "Some village-level organizations are but empty shells and are dominated and controlled by illegal religious forces" ${ }^{86}$ On the other hand, banning Uyghur officials and party members from religious activities alienates them from their constituents and undermines their ability to

\footnotetext{
${ }^{82}$ The profile of clerics is all the higher in Uyghur society as Uyghurs directly serving the state are seen as collaborators.

${ }^{83}$ Fuller and Lipman, "Islam in Xinjiang."; Shichor, "Blow up: internal and external challenges of Uyghur separatism and Islamic radicalism to Chinese rule in Xinjiang."; Mackerras, "Xinjiang in 2013: problems and prospects," 247-248; Andrew Jacobs, "Court sentences 2 teenagers to death in killing of an Islamic cleric," New York Times, 29 September 2014.

${ }^{84}$ Smith Finley, The Art of Symbolic Resistance: Uyghur Identities and Uyghur-Han Relations in Contemporary Xinjiang.

${ }^{85}$ Fuller and Lipman, "Islam in Xinjiang," 329, 336.

${ }^{86}$ Cited in Wayne, China's War on Terrorism: Counter-Insurgency, Politics and Internal Security, 93.
} 
create organic links with the state. ${ }^{87}$ At the heart of the matter, there is a dogged willingness on the part of Uyghur religious nationalists to wrest control from Chinese authorities, and an equally dogged willingness on the part of Chinese authorities to remain in control.

\section{Economic Relations}

More than in any other emerging market, economic relations in China are hardly separable from political relations. State regulation is still very tight, especially in the "backward" northwestern regions where most Muslims live. Yet, economic liberalization has led to a more differentiated picture, producing a variety of absolute and relative winners and losers. Among China’s Muslims, the Hui have largely benefitted from economic liberalization whereas Uyghurs are widely perceived, and perceive themselves, as relative losers. This reinforces the perception of a socio-spatial hierarchy between China’s Muslim minorities.

Take as an example the "Great Western Development” campaign that started in 1999 and is supposed to bring harmony to China's underdeveloped Western areas, and particularly to Xinjiang. ${ }^{88}$ In the characteristic carrots-and-sticks approach of the Chinese state towards Uyghurs, the development campaign is the economic carrot par excellence. But while there is no denial that Xinjiang’s Han and Hui communities have greatly benefitted from the campaign, we will see that Uyghurs complain about relative deprivation regardless of the fact that, in

\footnotetext{
${ }^{87}$ Stephen E. Hess, "Islam, local elites, and China's missteps in integrating the Uyghur nation," USAK Yearbook 3(2010): 407-428.

${ }^{88}$ Michael E. Clarke, "China's internal security dilemma and the "Great Western Development": the dynamics of integration, ethnic nationalism and terrorism in Xinjiang," Asian Studies Review 31, no. 3 (2007): 323-342;

Clarke, Xinjiang and China's Rise in Central Asia: A History, 129-156.
} 
absolute terms, even they have been left better off by the Great Western Development campaign and, more recently, by aspects of the "Silk Road Economic Belt" strategy. ${ }^{89}$

\section{Han-Hui relations}

Generalizations about the economic situation of the Hui are arduous due to the diversity of local circumstances, from rural communities in the mountainous northwest to urban communities on the east coast. Overall, however, the Hui have been quite successful in benefiting from economic liberalization in the wake of Deng Xiaoping’s 1978 reforms.

The most obvious case in point is halal (qingzhen) restaurants, which not only have a guaranteed outlet to Muslim customers but are also popular among Han Chinese customers. There are many other occupations where the Hui are doing well. In Qinghai, for example, the Hui have adapted to economic liberalization by reviving their pre-1949 economic niches running trucks or long-distance minibus services and as petty merchants and entrepreneurs, trading wool, furs, and animal hides from pastoral areas to urban customers. ${ }^{90}$

In the banking sector, there are some signs of economic segregation. Decades ago, Hui Muslims in Qinghai opened their own saving center at the Xining City Bank of Industry and Commerce because "Muslim money should be used for Muslim affairs."91 In 2009, Ningxia

\footnotetext{
${ }^{89}$ Colin Mackerras, "Xinjiang in China's foreign relations: part of a new silk road or Central Asian zone of conflict?," East Asia 32, no. 1 (2015): 25-42.

${ }^{90}$ Cooke, "Surviving state and society in Northwest China: the Hui experience in Qinghai Province under the PRC," 413-414. This is in line with the traditional Hui role as middlemen, or brokers, between Han and non-Han. See Lipman, "White hats, oil cakes, and common blood: the Hui in the contemporary Chinese state," 31.

${ }^{91}$ Dillon, China's Muslim Hui Community: Migration, Settlement and Sects, 176-177.
} 
Bank started a pilot scheme of Islamic banking, with mixed results. ${ }^{92}$ In 2011, a bank in Lanzhou, Gansu province, introduced a Muslim credit card, called “Crescent and Star Card”. 93

Obviously, there are tight limits to such economic segregation. In the 1980s, a number of Hui mosques were revitalizing the classical Muslim institution of waqf, or endowed property generating a regular income for a religious institution. Especially in Ningxia, mosques exploited tax breaks and other fiscal incentives to become business players, which helped them in financing their activities. For example, in 1986 the Nanguan Mosque in Yinchuan set up its own hotel, canteen, grocery, shop, and clinic. ${ }^{94}$ In 1988, there were at least two comparable cases at mosques in Beijing (Qianmen and Mentougou). ${ }^{95}$ After a policy reversal in the 1990s, any official reporting of waqf-type practices has come to a halt, although there are various informal arrangements continuing and emerging in Ningxia, Qinghai, and Gansu. ${ }^{96}$

In line with their high status in the informal socio-spatial hierarchy of Muslim minorities, the Hui are often seen as a valuable "Islamic card" to promote international trade. When sending workers to Muslim-majority countries, Chinese companies often use subsidiaries headed by Hui Muslims and rely on Hui as cultural consultants. The Hui are thus treated as useful prox-

\footnotetext{
92 Xinhua, "Ningxiayinhang huozhun shidian kaiban yisilan yinhangyewu (Ningxia Bank has been officially approved to establish its pilot Islamic banking services)," 25 December 2009; Xinhua, "Ningxia yuanjing: sheli yisilan jinrongzhongxin (Ningxia vision: the establishment of an Islamic financial centre)," 26 November 2012; Erie, China and Islam: The Prophet, the Party, and Law, 288-299.

${ }^{93}$ See http://cn.unionpay.com/gansu/cup_gs_scdt/file_80165781.html (accessed on 8 January 2016).

${ }^{94}$ Lipman, "White hats, oil cakes, and common blood: the Hui in the contemporary Chinese state," 37.

${ }^{95}$ Welcome to Islam, "Beijingshi Qingzhensi (Mosques of Beijing)," http://www.yslzc.com/shu/Class103/zgqzs/200605/7842.html.

${ }^{96}$ Erie, China and Islam: The Prophet, the Party, and Law, 281-288.
} 
ies to facilitate better trade relations with the Muslim world. ${ }^{97}$ Especially in Ningxia (less so in other provinces and regions), the Hui have been able to attract considerable investment and even charitable donations from the Middle East. Every year, Ningxia hosts the glamorous China-Arab States Economic and Trade Forum, as well as the "Halal Food Muslims Everyday Product Festival.” Needless to say, all of this is counterbalanced by concerns in Han circles that such relations might open the gates for religious influences from the Middle East. ${ }^{98}$

Even so, and on balance, the Hui are seen as an asset rather than a liability. In Yiwu, a market town in southeastern China, for example, Hui middlemen are systematically deployed as mercantile go-betweens between Han businessmen and their foreign Muslim clients. ${ }^{99}$

\section{Han-Uyghur relations}

Unlike the Hui, Uyghurs trading with Muslim countries are not seen as a desirable "Islamic card” but as dangerous incubators of extremism. Therefore, Uyghur trade links with Central Asia and Pakistan were disrupted in the early 2000s, with Han and Hui taking over. ${ }^{100}$ Since

${ }^{97}$ Gladney, Dislocating China: Reflections on Muslims, Minorities, and Other Subaltern Subjects, 57; Wai-Yip Ho, "Mobilizing the Muslim minority for China's development: Hui Muslims, ethnic relations and Sino-Arab connections," Journal of Comparative Asian Development 12, no. 1 (2013): 84-112.

${ }^{98}$ Erie, China and Islam: The Prophet, the Party, and Law, 295-302.

${ }^{99}$ Ibid., 206-214.

${ }^{100}$ Sean R. Roberts, "A "land of borderlands": implications of Xinjiang's trans-border interactions," in Xinjiang: China's Muslim Borderland, ed. S. Frederick Starr (Armonk, NY: M.E. Sharpe, 2004), 216-237, 220-225; Ziad Haider, "Sino-Pakistan relations and Xinjiang's Uighurs: politics, trade, and Islam along the Karakoram Highway," Asian Survey 45, no. 4 (2005): 522-545, 525-531; Hasan H. Karrar, "Merchants, markets, and the state: informality, transnationality, and spatial imaginaries in the revival of Central Eurasian trade," Critical Asian Studies 45, no. 3 (2013): 459-480, 466-467. 
then, Uyghurs have hardly been able to exploit their position as a Turkic people connecting China with Central Asia. Even in their home region of Xinjiang, the Uyghurs are low on the occupational food chain and have significantly lower per capita income than Han. ${ }^{101}$

More than 80 percent of Uyghurs work in agriculture, compared to “only” 37 percent of the Han. Conversely, more than 35 percent of Han work in high-status and high-paying jobs, compared to only 13 percent for Uyghurs. ${ }^{102}$ From the materialist perspective of the Chinese Communist Party, such structural marginalization is an important source of ethnoreligious resentment and separatism, calling for economic development as a solution. According to a 1996 report, “[a]ll we need to do is serve the various minzu in Xinjiang heart and soul, take economic development as the crux, lift up the economy, lift up education, and do a good job with United Front work and minzu religion work.”"103 More recently, the Party has shifted to a security-focused approach that places the emphasis on social stability, with "religious work" and economic development subservient to that objective. Despite the shift in emphasis, development continues to be regarded as a crucial part of any solution for Xinjiang. ${ }^{104}$

Partly in pursuit of this political strategy, the Great Western Development campaign has pushed growth rates in Xinjiang above national average. Paradoxically, however, the policy

${ }^{101}$ Han, Contestation and Adaptation: The Politics of National Identity in China, 57.

${ }^{102}$ Reza Hasmath, "Managing China's Muslim minorities: migration, labour and the rise of ethno-religious consciousness among Uyghurs in urban Xinjiang," in Religion and the State: A Comparative Sociology, ed. Jack Barbalet, Adam Possamai, and Bryan Turner (New York: Anthem Press, 2011), 121-137, 7-8.

${ }^{103}$ Cited in Gardner Bovingdon, "Heteronomy and its discontents: "Minzu regional autonomy" in Xinjiang," in Governing China's Multiethnic Frontiers, ed. Morris Rossabi (Seattle: University of Washington Press, 2004), 117-154, 147-148.

${ }^{104}$ Xinhua, "Xijinping zai di’erci zhongyangxinjianggongzuozuotanhuishang fabiao zhongyaojianghua (Xi Jinping delivered an important speech in the second Xinjiang Work Seminar of the CCCPC)," 30 May 2014. 
has led to an increased sense of deprivation among Uyghurs. The reason is that the marketoriented expansion has led to an increase of the private sector relative to the state sector. While affirmative action in the state sector continues to create an artificially level playing field, in the private sector Uyghurs tend to earn less than Han. A survey in Urumqi suggests that, after controlling for education and other factors, there is rough Uyghur-Han income parity in the state sector; but outside the state sector, Uyghurs earn less than half. ${ }^{105}$ Some explain this by discrimination and cronyism (guanxi), while others point to differences in culture and work ethic. Given that many Uyghurs strongly resent the Han and more than $80 \%$ are unable to read Mandarin, ${ }^{106}$ no conspiracy theory is needed to understand why many Han employers use their contractual freedom to hire Han or Hui rather than Uyghur workers. ${ }^{107}$

Despite the massive investment unlocked by the Great Western Development campaign, there is a vitriolic debate on how much, if anything, the Uyghurs are benefiting. While per capita income has increased for all sectors of the population including Uyghurs, there are bitter complaints about intercommunal disparities and the relative deprivation of Uyghurs as compared to the Han and Hui. ${ }^{108}$ Uyghur insurgents increasingly target Han and, to a lesser extent, Hui migrants rather than Chinese state officials and symbols of the state. ${ }^{109}$

\footnotetext{
105 Xiaowei Zang, "Uyghur-Han earnings differentials in Ürümchi," China Journal 65(2011): 141-155.

106 Timothy A. Grose, "The Xinjiang Class: education, integration, and the Uyghurs," Journal of Muslim Minority Affairs 31, no. 1 (2010): 97-109.

107 Yuchao Zhu and Dongyan Blachford, "Economic expansion, marketization, and their social impact on China's ethnic minorities in Xinjiang and Tibet," Asian Survey 52, no. 4 (2012): 714-733.

108 Barry Sautman, "Is Xinjiang an internal colony?," Inner Asia 2, no. 2 (2000): 239-271; Huhua Cao, "Urbanrural income disparity and urbanization: What is the role of spatial distribution of ethnic groups? A case study of Xinjiang Uyghur Autonomous Region in Western China," Regional Studies 44, no. 8 (2010): 965-982; Hasmath,
} 


\section{Societal Relations}

Interethnic relations are often rife with mutual stereotyping, which makes them an exceedingly difficult object of study. To avoid the risk of amplifying prejudice that may be prevalent among the participants, let us start this section with a reasonably objective measure for the quality of relations: the propensity of different ethnic groups to intermarry.

Until recently, in China there has been a peculiar incentive for intermarriage between Han and members of minority groups: the latter, including both the Hui and the Uyghurs, were exempt from the one-child policy, i.e. they could have two or more children. The exemption extended to mixed-marriage couples, which in most cases were automatically granted the right to have a second child. In rural areas, "ethnic” couples were often allowed to have even more than two children. A recent comparative survey demonstrates that the minority exemptions in Xinjiang and Ningxia were among the most generous found all over China. ${ }^{110}$

Minority exemptions from the one child policy created an incentive for Han to marry spouses from ethnic minorities, which in turn enabled people from a minority background to "marry up”, i.e. marry Han of more desirable economic and/or social extraction than would otherwise

\footnotetext{
"Managing China's Muslim minorities: migration, labour and the rise of ethno-religious consciousness among Uyghurs in urban Xinjiang."

${ }^{109}$ Isabelle Côté, "The enemies within: targeting Han Chinese and Hui minorities in Xinjiang," Asian Ethnicity 16, no. 2 (2015): 136-151.

${ }^{110}$ Danielle F.S. Cohen, "Minority Births under China's One-Child Policy. Paper Presented at the Annual Meeting of the International Studies Association, Toronto, Canada," (2014).
} 
have been possible. ${ }^{111}$ In a situation of positive inter-group relations, one would therefore predict high levels of intermarriage. The data however speaks a different language.

Nationwide, 91.6 percent of the Chinese population is Han, with the remainder made up of ethnic minorities. 2.7 percent of all Chinese households are bi-ethnic. It appears fair to assume that most of these bi-ethnic households result from intermarriage, although in some cases there may be other reasons. While inference is difficult at this aggregate level, the relatively low number suggests a certain level of communal segregation (Table 3).

\begin{tabular}{|l|l|l|l|l|l|}
\hline & Han (\%) & Non-Han (\%) & Hui (\%) & Uyghur (\%) & Bi-ethnic households (\%) \\
\hline Nationwide & 91.6 & 8.4 & 0.79 & 0.76 & 2.69 \\
\hline Ningxia & 63.64 & 36.36 & 35.60 & $<0.8$ & 1.98 \\
\hline Xinjiang & 38.0 & 62.0 & 4.6 & 47.4 & 1.37 \\
\hline
\end{tabular}

Table 3: Households by ethnicity. ${ }^{112}$

In Ningxia, the percentage of non-Han (almost all of whom are Hui) is more than four times the national average but the share of bi-ethnic households is less than the national average. While intermarriage between Han and Hui does occur, communal segregation makes it extremely rare. The situation is even more dramatic in Xinjiang, where more than 47 percent are Uyghur and more than 60 percent are non-Han. This includes 7 percent Kazak, 4.6 per-

\footnotetext{
${ }^{111}$ Rachel Butera and Thierry Warin, "Chinese interethnic marriage: passion or rational choice?," International Journal of Economics and Business Research 4, no. 6 (2012): 738-762.

112 Sources: National Bureau of Statistics of China, Tabulation on the 2010 Population Census of the People's Republic of China, Part I, Tables 2-1 and 5-3; Statistics Bureau of Xinjiang Uyghur Autonomous Region, Xinjiang tongji nianjian (Xinjiang Statistical Yearbook); Statistics Bureau of Ningxia Hui Autonomous Region, Ningxia tongji nianjian (Ningxia Statistical Yearbook).
} 
cent Hui, 0.9 percent Kyrgyz, 0.8 percent Mongolian, and another 1.3 percent from other minorities. ${ }^{113}$ Without prior knowledge, one might naively expect Xinjiang to have a high rate of intermarriage. On the face of it, however, the rate is even further below national average! This surely is an indicator that intercommunal segregation in Xinjiang is at its highest. ${ }^{114}$

To complement the regional-level data presented in Table 3, let us consider national-level rates for endogamy and intermarriage. Strikingly, the Uyghurs are more endogamous than any other of China’s 56 ethnic groups. A comparison of ethnic endogamy and intermarriage rates among the five most relevant ethnic groups yields the following picture (Table 4).

\begin{tabular}{|c|c|c|c|c|c|}
\hline & Han & Hui & Uyghur & Kazak & Dongxiang \\
\hline Han & 98.55 & 11.43 & 0.24 & 2.40 & 0.48 \\
\hline Hui & 0.10 & 87.06 & 0.07 & 0.38 & 11.39 \\
\hline Uyghur & 0.00 & 0.06 & 99.47 & 0.67 & 0.03 \\
\hline Kazak & 0.00 & 0.05 & 0.10 & 95.80 & 0.03 \\
\hline Dongxiang & 0.00 & 0.52 & 0.00 & 0.00 & 87.64 \\
\hline
\end{tabular}

Table 4: Ethnic endogamy and intermarriage rates. ${ }^{115}$

\footnotetext{
${ }^{113}$ Statistics Bureau of Xinjiang Uyghur Autonomous Region, Xinjiang tongji nianjian (Xinjiang Statistical Yearbook).

${ }^{114}$ After a meeting of the Politburo in 2014, the Chinese state has begun to experiment with financial incentives to promote intermarriage in Xinjiang. See James Leibold, "Xinjiang Work Forum marks new policy of 'ethnic mingling'," China Brief 14, no. 12 (2014): 3-6; Edward Wong, "China offers incentives to intermarry in Xinjiang," International New York Times, 3 September 2014.

${ }^{115}$ Calculations based on Department of Population and Employment Statistics of National Bureau of Statistics of China and Department of Economic Development of the State Ethnic Affairs Commission, Zhongguo
} 
Seven of the ten most endogamous ethnic groups in China are Muslim. ${ }^{116}$ Yet there is large variation, with the Uyghurs firmly in the lead. With a rate of 99.47 percent, the Uyghurs are even more endogamous than the Han (98.55\%) whom one would expect to be very endogamous given their preponderant share of the population. The Hui are far less endogamous (87.06\%), like the Mongolic Dongxiang (87.64\%). The Hui-Han intermarriage rate (11.43\%) is almost fifty times higher than the Uyghur-Han intermarriage rate $(0.24 \%)$. The case of the Kazaks demonstrates that other Turkic-speaking Muslim minorities living in Xinjiang are far more amenable to intermarriage with the Han (2.40\%) than the Uyghurs (0.24\%).

\section{Han-Hui relations}

As Table 4 suggests, Han-Hui intermarriage is not unheard of. Even so, Table 3 suggests that there must be some inhibitor making it less frequent than one might expect. In fact, there is ethnographic evidence to indicate that endogamy is often a conscious choice among the Hui. Men in isolated Hui villages tend to get their wives either from their own village and sometimes even from their own extended family, but those unwilling or unable to do so resort to remote Hui villages in faraway provinces rather than marrying some Han neighbour’s daugh-

2010nian renkoupucha fenminzu renkouziliao (Tabulation on Nationalities of the 2010 Population Census of China) (Beijing: Minzu chubanshe (Ethnic Publishing House), 2013), Table 4-4.

${ }^{116}$ Uyghurs 99.47\%; Han 98.55\%; Tajiks 97.16\%; Kazaks 95.80\%; Kirgiz 95.71\%; Tibetans 92.84\%; Koreans 89.94\%; Dongxiang 87.64\%; Hui 87.06\%; Salars 86.19\%. 
ter. ${ }^{117}$ A survey from Lanzhou suggests that differences in religion and lifestyle, including dietary requirements, are crucial inhibitors against intermarriage even in urban areas. ${ }^{118}$

There is a (moderate) propensity among Hui to be the dominant part in intermarriages with Han counterparts. The most frequent constellation is couples with a male Hui head of household, and the least frequent one is couples with a female Han head of household. ${ }^{119}$ The most likely reason is that Hui Muslims assume that the offspring from Han-dominated families will grow up as Han. As an intellectual from Beijing put it, “[t]here is a 'Great Wall' separating us Hui from the Han. We do not eat pork and we do not give them our women.”120 This biased pattern of intermarriage appears related to an ethnocentric understanding that Han can become Hui but the reverse is impossible. ${ }^{121}$ While this runs counter to the classical Confucian perspective, it chimes with a Muslim understanding that everybody can and should convert to Islam but a Muslim must never compromise his/her religious identity. Ethnographic scholarship suggests that even urban Hui often require conversion to Islam for intermarriage. ${ }^{122}$

\footnotetext{
${ }^{117}$ Gladney, Muslim Chinese: Ethnic Nationalism in the People's Republic, 229-259.

${ }^{118}$ Xiaowei Zang, "Hui Muslim - Han Chinese differences in perceptions on endogamy in urban China," Asian
} Ethnicity 6, no. 1 (2005): 51-68.

${ }^{119}$ Families with male Hui head of household: 213,751. Families with male Han head of household: 196,873. Families with female Hui head of household: 52,331. Families with female Han head of household: 36,110.

${ }^{120}$ Cited in Gladney, Muslim Chinese: Ethnic Nationalism in the People's Republic, 230.

${ }^{121}$ Ibid., 245.

${ }^{122}$ Maris Gillette, Between Mecca and Beijing: Modernization and Consumption Among Urban Chinese Muslims (Stanford, CA: Stanford University Press, 2000), 131-132. Historically, asymmetric intermarriage is at least in part how the Hui community used to grow in past epochs, gradually increasing their population share through offspring from non-Muslim women. See Gladney, "Islam in China: accommodation or separatism?," 464; Gladney, "Islam in China: state policing and identity politics," 160. 
Even so, the Hui have become accustomed to the fact that they occupy an inferior though privileged place in the Han socio-spatial hierarchy. Having negotiated for centuries their identity as Muslims in a non-Muslim environment, the Hui are notorious for their "trained self-censorship.”" 23 Their religious names, which are frequently derived from Koranic Arabic or Persian names, are predominantly for internal use, and depending on circumstances they may or may not be displayed on their business cards. ${ }^{124}$ In a peculiar kind of cultural mimicry, Hui mosques traditionally resemble Chinese temple architecture. This has been changing, however. Mosques constructed or reconstructed after the Cultural Revolution tend to emulate architectural styles familiar from the Middle East and/or Central Asia. ${ }^{125}$

In Han circles, Hui cohesion is often seen with suspicion. In Lanzhou, Gansu, Han informers bemoan that Hui carry the day in fist-fights against Han because other Hui would join their coreligionists whereas Han would stand by. ${ }^{126}$ The Hui are seen as "sticking together”, and for all but the politically incorrect turn of phrase that notion appears even in academic texts. ${ }^{127}$ While in the northwest there is considerable evidence in support of the stereotype, in the southeast it is quite common for Hui families to live in mixed urban neighborhoods. In these areas, assimilation has erased almost any tangible marker of distinction. ${ }^{128}$ Another

\footnotetext{
${ }^{123}$ Frankel, "'Apoliticization': one facet of Chinese Islam," 423.

${ }^{124}$ Dillon, China's Muslims, 53.

${ }^{125}$ Ibid., 38.

${ }^{126}$ Xiaowei Zang, Ethnicity and Urban Life in China: A Comparative Study of Hui Muslims and Han Chinese (London: Routledge, 2007).

${ }^{127}$ Zhijuan Yang, "Zuqunrentong yu minzu de jieding: yi huizu weili (National identity and the demarcation of a nation: a case study of Hui)," Huizu yanjiu (Journal of Hui Muslim Minority Studies) 40, no. 4 (2000): 4-8. ${ }^{128}$ Cooke, "Surviving state and society in Northwest China: the Hui experience in Qinghai Province under the PRC."
} 
conventional stereotype, sometimes amplified by the Communist Party, is that the Hui are “feudal”, "backward”, “of low cultural quality”, and “troublesome”. ${ }^{129}$

While many Hui have internalized such notions of inferiority and benefit from related positive discrimination, others showcase a belief that “authentic” Islam is superior to any other civilization, pointing to Arab prosperity as evidence. ${ }^{130}$ Some refer to Islam as a complete way of life and emphasize that coexistence between the Hui and the Han is bound to be awkward for both sides. ${ }^{131}$ In 2000, after a non-Muslim street vendor in Shandong Province had put up a sign advertising “Muslim pork”, initially peaceful protests escalated into a violent standoff with state forces when hundreds if not thousands of Muslims from nearby Hebei Province were trying to join the rally. ${ }^{132}$ A similar incident happened in 2015 in Anhui Province, after Muslims had discovered that the "halal” (qingzhen) brand was abused to produce pork and other food. ${ }^{133}$ All of this indicates that Han-Hui relations are sometimes more difficult than official proclamations of social harmony suggest—but even though Han-Hui relations are far from always harmonious, they are certainly better than Han-Uyghur relations.

\footnotetext{
${ }^{129}$ Gillette, Between Mecca and Beijing: Modernization and Consumption Among Urban Chinese Muslims. ${ }^{130}$ Ibid., Ch. 2 and 8.

${ }^{131}$ Osman Chuah, "Muslims in China: the social and economic situation of the Hui Chinese," Journal of Muslim Minority Affairs 24, no. 1 (2004): 155-162.

${ }^{132}$ Lipman, "White hats, oil cakes, and common blood: the Hui in the contemporary Chinese state," 45-46.

133 http://www.boxun.com/news/gb/china/2015/10/201510231525.shtml\#.Vo_bcU1FDmh; http://www.2muslim.com/forum.php?mod=viewthread\&tid=746912 (both accessed on 8 January 2016).
} 


\section{Han-Uyghur relations}

Ethnographic research suggests that, ever since the 1990s, the Uyghurs have increasingly made social segregation, including the taboo against intermarriage and the Islamic halal diet, a point of ethno-nationalist honor—what Joanne Smith Finley calls “symbolic resistance.”134 Ethnographers have found that “a Uyghur marrying a Han Chinese would be disowned by his or her family, and would constantly be harassed and scolded within the Uyghur community.”135 In Xinjiang’s male-dominated and ostentatiously religious society, it is not surprising that, following Islamic rules, Muslim women are not allowed to marry non-Muslims. This is despite the fact that Muslim social and religious rules would allow Muslim males to marry non-Muslim females as long as the latter are willing to bring up the children as Muslims. ${ }^{136}$

With less than 10,000 cases in the whole of China, Han-Uyghur intermarriage is extremely rare. ${ }^{137}$ Meticulous ethnographic research has demonstrated that this is based on a Uyghur rather than a Han taboo. ${ }^{138}$ Uyghurs are less prone to intermarriage than any other ethnic group. As we have seen, Uyghurs already had the lowest rate of interethnic marriage among all of China's 56 ethnic groups in 2000, with 1.05 percent. Since then, the figure has halved

\footnotetext{
${ }^{134}$ Smith Finley, The Art of Symbolic Resistance: Uyghur Identities and Uyghur-Han Relations in Contemporary Xinjiang.

${ }^{135}$ Enze Han, "Boundaries, discrimination, and interethnic conflict in Xinjiang, China," International Journal of Conflict and Violence 4, no. 2 (2010): 244-256, 250.

${ }^{136}$ Fuller and Lipman, "Islam in Xinjiang," 321.

${ }^{137}$ Families with male Uyghur head of household: 3,166. Families with female Uyghur head of household: 686. Families with male Han head of household: 4,766. Families with female Han head of household: 508. ${ }^{138}$ Smith Finley, The Art of Symbolic Resistance: Uyghur Identities and Uyghur-Han Relations in Contemporary Xinjiang, 294-348.
} 
to 0.53 percent, whereas interethnic marriages for other groups have held steady. ${ }^{139}$ Uyghur exogamy is even lower in the traditionalist and segregated areas of southern Xinjiang. ${ }^{140}$

In the few cases where a Uyghur undertakes intermarriage, the spouse is Han in less than half of the cases. Religion is the inhibitor most frequently cited, but this is only part of the story. Uyghurs are even less likely to intermarry with Hui Muslims than with Han. ${ }^{141}$ This is in line with the socio-spatial hierarchy: many Uyghurs see the Hui as political proxies of the Han, and as culturally Chinese rather than religiously Muslim. ${ }^{142}$ Once again, we can see how centuries of Hui acculturation and Han-Uyghur confrontation have driven a wedge between the two groups of Muslims. Uyghur-Kazak intermarriage is also quite rare (see Table 4).

Identity politics is rampant in Xinjiang, one of China's most multiethnic regions. Uyghurs stereotype their Kazak coreligionists and Central Asian co-ethnics as nomadic and less au-

\footnotetext{
${ }^{139}$ Zhongyi Liu and Li Zhang, "Zhongguo zujihunyin de bianhua queshi yanjiu: jiyu 'Wupu' he 'Liupu' shuju de duibifenxi (A study on changing trends in China's inter-ethnic marriage: based on the comparison of data from the fifth and sixth census)," Guangxi minzuyanjiu (Guangxi Ethnic Studies) 123, no. 3 (2015): 61-71; Xiaoxia Li, "Zhongguo ge minzu jian zuji hunyin de xianzhuang fenxi (Analysis of the current state of inter-ethnic marriage among different Chinese ethnic groups)," Renkou yanjiu (Population Research) 28, no. 3 (2004): 68-75.

${ }^{140}$ Xiaoxia Li, "Xinjiang nanbu nongcun weihantonghun diaocha (Investigation on intermarriage between Uyghurs and Han in rural areas of southern Xinjiang)," Xinjiang shehuikexue (Social Sciences in Xinjiang) 179, no. 4 (2012): 59-66.

${ }^{141}$ Families with male Hui head of household: 1,359. Families with female Hui head of household: 105. Families with male Uyghur head of household: 855. Families with female Uyghur head of household: 174. ${ }^{142}$ Smith Finley, The Art of Symbolic Resistance: Uyghur Identities and Uyghur-Han Relations in Contemporary Xinjiang.
} 
thentically Muslim due to their shamanistic legacy. ${ }^{143}$ What is more, Uyghur xenophobia appears to extend far beyond anti-Han sentiment. At the 2009 Urumqi riots, Uyghurs chanted “Kill the Han, kill the Hui,” "Cut the Kazaks,” and "Drive the Mongols out.”144

Ethnographers have found that intergroup resentment runs high and violence can flare up any time, whether on the marketplace or in a dance hall. ${ }^{145}$ While it is true that few Han bother to learn the Uyghur language, it is mostly the Uyghurs who set the terms of segregation. ${ }^{146}$ Thus, Uyghur youth sometimes take their female partners to the more discreet Chinese dance halls, but a Han girl would hardly be tolerated in a Uyghur establishment. Han are frequent guests in Uyghur restaurants, but Uyghurs insist that they cannot enter Han restaurants for fear of contamination with pork. ${ }^{147}$ Uyghurs sometimes extend hospitality to Han but, with similar excuses, usually won't accept an invitation in the other direction. In one case, Uyghurs even objected to sharing a hospital ward with Han patients and their visitors. ${ }^{148}$

\footnotetext{
${ }^{143}$ Lipman, "White hats, oil cakes, and common blood: the Hui in the contemporary Chinese state," 51; Han, "Boundaries, discrimination, and interethnic conflict in Xinjiang, China," 252.

${ }^{144}$ Hannah Beech, "If China is anti-Islam, why are these Chinese Muslims enjoying a faith revival?," Time, 12 August 2014; Côté, "The enemies within: targeting Han Chinese and Hui minorities in Xinjiang," 140.

145 Ildikó Bellér-Hann, "Temperamental neighbours: Uighur-Han relations in Xinjiang, Northwest China," in Imagined Differences: Hatred and the Construction of Identity, ed. Günther Schlee (Hamburg: LIT, 2002), 5781, 52.

${ }^{146}$ Smith Finley, The Art of Symbolic Resistance: Uyghur Identities and Uyghur-Han Relations in Contemporary Xinjiang, 130-172; Joanne N. Smith, "'Making culture matter": symbolic, spatial and social boundaries between Uyghurs and Han Chinese," Asian Ethnicity 3, no. 2 (2002): 153-174.

${ }^{147}$ Uyghurs strictly observe the Islamic prohibition against eating pork, yet alcohol, drugs, and sexual promiscuity are rampant in parts of Uyghur society. See Fuller and Lipman, "Islam in Xinjiang."

148 Bellér-Hann, "Temperamental neighbours: Uighur-Han relations in Xinjiang, Northwest China," 74.
} 
Intercommunal resentment between Uyghurs and Han is not only of an ethnic nature but also has religious overtones. Han use expressions like “towel-head” (chantou) for Uyghurs, and Uyghurs use expressions like kapir for the Han, a term derived from the Arabic word for infidel. ${ }^{149}$ The litany of anti-Han stereotypes among Uyghurs easily fills forty pages. ${ }^{150}$ This demonstrates that the socio-spatial distance between Han and Uyghurs is not only entrenched on both sides but also reinforced by resentment that will be hard to overcome.

\section{Conclusion}

China looks back to an ancient tradition of relying on ethnic and religious minority groups to control or constrain other such groups (yiyi zhiyi). This has left its legacy, namely a sociospatial hierarchy according to which certain groups are more of an asset and others more of a liability. The Sinicized Hui (and others like the Kazaks) are in the former category, and the Uyghurs (and others like the Tibetans) in the latter. This article has shown that the hierarchy is reflected in Han-Muslim relations at the political, economic, and societal level.

From a liberal perspective, this is disturbing because it has clear elements of discrimination. It is also regrettable from a Han perspective because it frustrates attempts to mend fences with those Muslim groups who, like the Uyghurs, fall at the lower end of the socio-spatial hierarchy. Yet, the hierarchy also performs an important function in that it enables the Chinese majority to manage a set of otherwise highly challenging relationships.

\footnotetext{
149 Bovingdon, The Uyghurs: Strangers in Their Own Land, 89.

${ }^{150}$ Smith Finley, The Art of Symbolic Resistance: Uyghur Identities and Uyghur-Han Relations in Contemporary Xinjiang, 82-129.
} 
Besides, it seems unfair to attribute to China all the blame for the tense situation in Xinjiang. This is not to deny that, after decades of ethno-religious contestation, Uyghurs have accumulated grievances, but not all of them are equally justified. Uyghurs rightly complain about discrimination, but rarely mention that they benefit from affirmative action. Uyghurs often cite Han migration to Xinjiang as a major grievance, and it is true that, in the 1950s and 1960s, the demographic status of Uyghurs in Xinjiang declined from that of an overwhelming majority to the largest ethnic group, followed by the Han. However, census data shows that the population share of Xinjiang's Han has levelled off in the early 1980s. For the last 30 years, higher reproduction rates among Uyghurs have offset the net influx of Han migrants. ${ }^{151}$

Critics may retort that self-determination is the answer to the "Uyghur question". Or is it? Realistically speaking, the result of self-determination might be the Uyghurs (47 percent of Xinjiang's population) turning the tables against the Han (38 percent), with other minorities caught in the middle. What is more, it is debatable how much if anything the Uyghurs would benefit from self-determination. Ordinary Muslims in post-Soviet Central Asian republics such as Kyrgyzstan and Tajikistan are hardly better off than the Uyghurs in China.

As suggested at the very beginning of this article, maintaining stability in a Muslim-majority area like Xinjiang is genuinely difficult for a non-Muslim country. Situations like Indian Kashmir and the Russian North Caucasus are important cases in point. Western countries increasingly face growing Muslim minorities in urban areas. Will they fare any better than China once there are Muslim majorities on significant parts of their territory?

\footnotetext{
${ }^{151}$ Statistics Bureau of Xinjiang Uyghur Autonomous Region, Xinjiang tongji nianjian (Xinjiang Statistical Yearbook), Tables 3-3 and 3-8. Like elsewhere in China, there is a significant number of undocumented internal migrants, called "self-drifters", but Chinese authorities by definition do not directly control their influx and their numbers are unknown.
} 
Unlike comparable situations abroad, China’s non-Muslim Han majority remains in control. As we have seen, despite some problems this is clearly the case in the political and economic sphere. Only in the societal sphere, Uyghurs increasingly set the terms of the relationship. For example, Uyghurs appear to be more xenophobic and opposed to intermarriage than Han. Even so, there is little solidarity between China’s diverse Muslim minorities, and least of all between the two largest ethnic groups, the Uyghurs and the Hui. China’s informal sociospatial hierarchy of minorities persists, as well as the ancient imperial legacy of yiyi zhiyi. 


\section{References}

Al-Sudairi, Mohammed Turki A. "Adhering to the Ways of Our Western Brothers: Tracing Saudi Influences on the Development of Hui Salafism in China." Sociology of Islam 4, no. 1 (2016): 27-58.

Atwill, David G. The Chinese Sultanate: Islam, Ethnicity, and the Panthay Rebellion in Southwest China, 1856-1873. Stanford, CA: Stanford University Press, 2005.

Authors' Collective. Huizu Jianshi (Brief History of the Hui Nationality). Beijing: Ethnic Publishing House, 2009.

Beech, Hannah. "If China Is Anti-Islam, Why Are These Chinese Muslims Enjoying a Faith Revival?" Time, 12 August 2014.

Bellér-Hann, Ildikó. "The “Gateway to the Western Regions”: State-Society Relations and Differentiating Uighur Marginality in China’s Northwest." edited by Zsombor Rajkai and Ildikó Bellér-Hann, 203-222. Wiesbaden: Harrassowitz, 2012, 203-222.

—_. "Temperamental Neighbours: Uighur-Han Relations in Xinjiang, Northwest China." In Imagined Differences: Hatred and the Construction of Identity, edited by Günther Schlee, 57-81. Hamburg: LIT, 2002, 57-81.

Benite, Zvi Ben-Dor. The Dao of Muhammad: A Cultural History of Muslims in Late Imperial China. Cambridge, MA: Harvard University Asia Center, 2005.

Benson, Linda. "Education and Social Mobility among Minority Populations in Xinjiang." In Xinjiang: China's Muslim Borderland, edited by S. Frederick Starr, 190-215. Armonk, NY: M.E. Sharpe, 2004, 190-215.

—. The Ili Rebellion: The Moslem Challenge to Chinese Authority in Xingjiang, 19441949. Armonk, NY: M.E. Sharpe, 1990. 
Benson, Linda, and Ingvar Svanberg. China's Last Nomads: The History and Culture of China's Kazaks. Armonk, NY: M.E. Sharpe, 1998.

Blum, Susan D. Portraits of "Primitives": Ordering Human Kinds in the Chinese Nation. Lanham: Rowman \& Littlefield, 2001.

Bovingdon, Gardner. "Heteronomy and Its Discontents: "Minzu Regional Autonomy" in Xinjiang." In Governing China's Multiethnic Frontiers, edited by Morris Rossabi, 117-154. Seattle: University of Washington Press, 2004, 117-154.

- The Uyghurs: Strangers in Their Own Land. New York: Columbia University Press, 2010.

Butera, Rachel, and Thierry Warin. "Chinese Interethnic Marriage: Passion or Rational Choice?" International Journal of Economics and Business Research 4, no. 6 (2012): 738-762.

Cao, Huhua. "Urban-Rural Income Disparity and Urbanization: What Is the Role of Spatial Distribution of Ethnic Groups? A Case Study of Xinjiang Uyghur Autonomous Region in Western China." Regional Studies 44, no. 8 (2010): 965-982.

CCP. "Chinese Communist Party Central Committee Document No. 7: Record of the Meeting of the Standing Committee of the Politburo of the Chinese Communist Party Concerning the Maintenance of Stability in Xinjiang." Human Rights Watch 10, no. 1 [C] (1996): 10-14.

Chuah, Osman. "Muslims in China: The Social and Economic Situation of the Hui Chinese." Journal of Muslim Minority Affairs 24, no. 1 (2004): 155-162.

Clarke, Michael E. "China's Internal Security Dilemma and the "Great Western Development": The Dynamics of Integration, Ethnic Nationalism and Terrorism in Xinjiang." Asian Studies Review 31, no. 3 (2007): 323-342.

—. Xinjiang and China's Rise in Central Asia: A History. London: Routledge, 2011. 
Cohen, Danielle F.S. "Minority Births under China's One-Child Policy. Paper Presented at the Annual Meeting of the International Studies Association, Toronto, Canada." 2014.

Cooke, Susette. "Surviving State and Society in Northwest China: The Hui Experience in Qinghai Province under the Prc." Journal of Muslim Minority Affairs 28, no. 3 (2008): 401-420.

Côté, Isabelle. "The Enemies Within: Targeting Han Chinese and Hui Minorities in Xinjiang." Asian Ethnicity 16, no. 2 (2015): 136-151.

Department of Population and Employment Statistics of National Bureau of Statistics of China, and Department of Economic Development of the State Ethnic Affairs Commission. Zhongguo 2010nian Renkoupucha Fenminzu Renkouziliao (Tabulation on Nationalities of the 2010 Population Census of China). Beijing: Minzu chubanshe (Ethnic Publishing House), 2013.

Dillon, Michael. China's Muslim Hui Community: Migration, Settlement and Sects. Richmond, UK: Curzon, 1999.

—. China's Muslims. Hong Kong: Oxford University Press, 1996.

—. Xinjiang: China's Muslim Far Northwest. London: Routledge, 2004.

Erie, Matthew S. China and Islam: The Prophet, the Party, and Law. New York: Cambridge University Press, 2016.

Forbes, Andrew D. W. Warlords and Muslims in Chinese Central Asia: A Political History of Republican Sinkiang 1911-1949. Cambridge: Cambridge University Press, 1986.

Frankel, James D. "'Apoliticization': One Facet of Chinese Islam." Journal of Muslim Minority Affairs 28, no. 3 (2008): 421-434.

_ . "Chinese-Islamic Connections: An Historical and Contemporary Overview." Journal of Muslim Minority Affairs 36, no. 4 (2016): 569-583. 
—. Rectifying God's Name: Liu Zhi's Confucian Translation of Monotheism and Islamic Law. Honolulu: University of Hawaii Press, 2011.

Fuller, Graham E., and Jonathan N. Lipman. "Islam in Xinjiang." In Xinjiang: China's Muslim Borderland, edited by S. Frederick Starr, 320-352. Armonk, NY: M.E. Sharpe, 2004, 320-352.

Gillette, Maris. Between Mecca and Beijing: Modernization and Consumption among Urban Chinese Muslims. Stanford, CA: Stanford University Press, 2000.

—_ "Violence, the State, and a Chinese Muslim Ritual Remembrance." Journal of Asian Studies 67, no. 3 (2008): 1011-1037.

Gladney, Dru C. Dislocating China: Reflections on Muslims, Minorities, and Other Subaltern Subjects. Chicago: University of Chicago Press, 2004.

_. "Islam in China: Accommodation or Separatism?" China Quarterly 174 (2003): 451467.

—_. "Islam in China: State Policing and Identity Politics." In Making Religion, Making the State, edited by Yoshiko Ashiwa and David L. Wank, 151-178. Stanford, CA: Stanford University Press, 2009, 151-178.

—. Muslim Chinese: Ethnic Nationalism in the People's Republic. 2nd ed. Cambridge, MA: Cambridge University Press, 1996.

—. "Salman Rushdie in China: Religion, Ethnicity, and State Definition in the People’s Republic." In Asian Visions of Authority: Religion and Modern States of East and Southeast Asia, edited by Charles F. Keyes, Laurel Kendall and Helen Hardacre, 255278. Honolulu: University of Hawaii Press, 1994, 255-278.

Grose, Timothy A. "(Re)Embracing Islam in Neidi: The 'Xinjiang Class' and the Dynamics of Uyghur Ethno-National Identity." Journal of Contemporary China 24, no. 91 (2015): 101-118. 
—. "The Xinjiang Class: Education, Integration, and the Uyghurs." Journal of Muslim Minority Affairs 31, no. 1 (2010): 97-109.

Haider, Ziad. "Sino-Pakistan Relations and Xinjiang's Uighurs: Politics, Trade, and Islam Along the Karakoram Highway." Asian Survey 45, no. 4 (2005): 522-545.

Han, Enze. "Boundaries, Discrimination, and Interethnic Conflict in Xinjiang, China." International Journal of Conflict and Violence 4, no. 2 (2010): 244-256.

- Contestation and Adaptation: The Politics of National Identity in China. Oxford: Oxford University Press, 2013.

Hann, Chris. "Laiklik and Legitimation in Rural Eastern Xinjiang." In Varieties of Secularism in Asia: Anthropological Explorations in Religion, Politics and the Spiritual, edited by Nils Bubandt and Martin van Beek, 121-241. London: Routledge, 2012, 121-241. Harrell, Stevan, ed. Cultural Encounters on China's Ethnic Frontiers. Seattle: University of Washington Press, 1995.

Hasmath, Reza. "The Education of Ethnic Minorities in Beijing." Ethnic and Racial Studies 34, no. 11 (2011): 1835-1854.

—. "Managing China's Muslim Minorities: Migration, Labour and the Rise of EthnoReligious Consciousness among Uyghurs in Urban Xinjiang." In Religion and the State: A Comparative Sociology, edited by Jack Barbalet, Adam Possamai and Bryan Turner, 121-137. New York: Anthem Press, 2011, 121-137.

Hernández, Javier C. "China Acknowledges Killing 28 People; Accuses Them of Role in Mine Attack." New York Times, 20 November 2015.

—_ "China Says 5 Killed in Attack at Communist Party Office in Xinjiang." New York Times, 30 December 2016.

Hess, Stephen E. "Islam, Local Elites, and China's Missteps in Integrating the Uyghur Nation." USAK Yearbook 3 (2010): 407-428. 
Ho, Wai-Yip. "Mobilizing the Muslim Minority for China's Development: Hui Muslims, Ethnic Relations and Sino-Arab Connections." Journal of Comparative Asian Development 12, no. 1 (2013): 84-112.

Hsing, I-tien. "Handai De Yiyizhiyilun (the Theory of 'Using Barbarians to Control Barbarians’ in the Han Dynasty)." Shiyuan (Journal of Historical Review) 5, no. 2 (1974): 9-53.

Hyer, Eric. "China's Policy Towards Uighur Nationalism." Journal of Muslim Minority Affairs 26, no. 1 (2006): 75-86.

Israeli, Raphael. Islam in China: Religion, Ethnicity, Culture, and Politics. Lanham, MD: Lexington Books, 2002.

Jacobs, Andrew. "Court Sentences 2 Teenagers to Death in Killing of an Islamic Cleric." New York Times, 29 September 2014.

—. "Light Government Touch Lets China's Hui Practice Islam in the Open." New York Times, 2 February 2016.

_ _ "Nearly 100 Reported Killed in Week of Unrest in China." New York Times, 3 August 2014.

—_. "Uyghurs in China Say Bias Is Growing." New York Times, 8 October 2013. Jaschok, Maria, and Jingjun Shui. The History of Women's Mosques in Chinese Islam: A Mosque of Their Own. Richmond, UK: Curzon, 2000.

Karrar, Hasan H. "Merchants, Markets, and the State: Informality, Transnationality, and Spatial Imaginaries in the Revival of Central Eurasian Trade." Critical Asian Studies 45, no. 3 (2013): 459-480.

Ke, Fan. "Maritime Muslims and Hui Identity: A South Fujian Case." Journal of Muslim Minority Affairs 21, no. 2 (2001): 309-332. 
—_. "Ups and Downs: Local Muslim History in South China." Journal of Muslim Minority Affairs 23, no. 1 (2003): 63-87.

Kim, Hodong. Holy War in China: The Muslim Rebellion and State in Chinese Central Asia, 1864-1877. Stanford, CA: Stanford University Press, 2004.

Kuo, Kendrick T. "Revisiting the Salafi-Jihadist Threat in Xinjiang." Journal of Muslim Minority Affairs 32, no. 4 (2012): 528-544.

Legge, James. The Chinese Classics. Vol. 3. Hongkong and London: Trübner \& Co., 1865.

Leibold, James. "Xinjiang Work Forum Marks New Policy of 'Ethnic Mingling'." China Brief 14, no. 12 (2014): 3-6.

Leibold, James, and Timothy A. Grose. "Veiling in Xinjiang: The Political and Societal Struggle to Define Uyghur Female Adornment." China Journal, no. 76 (2016): 78102.

Leung, Beatrice. "China's Religious Freedom Policy: The Art of Managing Religious Activity." China Quarterly 184 (2005): 894-913.

Li, Cheng. "Ethnic Minority Elites in China's Party-State Leadership: An Empirical Assessment." China Leadership Monitor 25 (2005).

Li, Xiaoxia. "Xinjiang Nanbu Nongcun Weihantonghun Diaocha (Investigation on Intermarriage between Uyghurs and Han in Rural Areas of Southern Xinjiang)." Xinjiang shehuikexue (Social Sciences in Xinjiang) 179, no. 4 (2012): 59-66.

—_. "Zhongguo Ge Minzu Jian Zuji Hunyin De Xianzhuang Fenxi (Analysis of the Current State of Inter-Ethnic Marriage among Different Chinese Ethnic Groups)." Renkou yanjiu (Population Research) 28, no. 3 (2004): 68-75.

Lipman, Jonathan. Islamic Thought in China: Sino-Muslim Intellectual Evolution from the 17h to the 21st Century. Edinburgh: Edinburgh University Press, 2016. 
Lipman, Jonathan N. Familiar Strangers: A History of Muslims in Northwest China. Seattle: University of Washington Press, 1997.

—_. "White Hats, Oil Cakes, and Common Blood: The Hui in the Contemporary Chinese State." In Governing China's Multiethnic Frontiers, edited by Morris Rossabi, 19-52. Seattle: University of Washington Press, 2004, 19-52.

Liu, Zhongyi, and Li Zhang. "Zhongguo Zujihunyin De Bianhua Queshi Yanjiu: Jiyu 'Wupu' He 'Liupu' Shuju De Duibifenxi (a Study on Changing Trends in China's Inter-Ethnic Marriage: Based on the Comparison of Data from the Fifth and Sixth Census)." Guangxi minzuyanjiu (Guangxi Ethnic Studies) 123, no. 3 (2015): 61-71.

Ma, Rong. "Xinjiang Minzujiaoyu De Fazhan Yu Shuangyujiaoyu De Shijian (Minority Education and the Practice of Bilingual Teaching in Xinjiang)." Beijingdaxue jiaoyupinglun (Peking University Education Review) 6, no. 2 (2008): 2-41.

Ma, Rosey Wang. "The Silent March: Unveiling the Gentle Power Behind the Consolidation of Islam in the Western Region of China." World Journal of Islamic History and Civilization 2, no. 2 (2012): 108-115.

Mackerras, Colin. "Some Issues of Ethnic and Religious Identity among China's Islamic Peoples." Asian Ethnicity 6, no. 1 (2005): 3-18.

—_. "Xinjiang in 2013: Problems and Prospects." Asian Ethnicity 15, no. 2 (2014): 247250.

—. "Xinjiang in China's Foreign Relations: Part of a New Silk Road or Central Asian Zone of Conflict?" East Asia 32, no. 1 (2015): 25-42.

McCarthy, Susan K. Communist Multiculturalism: Ethnic Revival in Southwest China. Seattle: University of Washington Press, 2009.

Millward, James A. Eurasian Crossroads: A History of Xinjiang. London: Hurst, 2007. 
National Bureau of Statistics of China. Tabulation on the 2010 Population Census of the People's Republic of China. Beijing: China Statistics Press, 2013.

Nechepurenko, Ivan. "Bomber Strikes Chinese Embassy in Kyrgyzstan." New York Times, 31 August 2016.

Rimsky-Korsakoff Dyer, Svetlana. Soviet Dungans in 1985: Birthdays, Weddings, Funerals and Kolkhoz Life. Taipei: Center for Chinese Studies, 1991.

Roberts, Sean R. "A "Land of Borderlands": Implications of Xinjiang's Trans-Border Interactions." In Xinjiang: China's Muslim Borderland, edited by S. Frederick Starr, 216-237. Armonk, NY: M.E. Sharpe, 2004, 216-237.

Rossabi, Morris. "Muslim and Central Asian Revolts." In From Ming to Ch'ing: Conquest, Region, and Continuity in Seventeenth Century China, edited by Jonathan D. Spence and John E. Wills, 167-199. New Haven: Yale University Press, 1979, 167-199.

Rudelson, Justin Jon. Oasis Identities: Uyghur Nationalism Along China's Silk Road. New York: Columbia University Press, 1997.

Sautman, Barry. "Is Xinjiang an Internal Colony?" Inner Asia 2, no. 2 (2000): 239-271.

—_. "Preferential Policies for Ethnic Minorities in China: The Case of Xinjiang." Nationalism and Ethnic Politics 4, no. 1 (2005): 86-118.

Shichor, Yitzhak. "Blow Up: Internal and External Challenges of Uyghur Separatism and Islamic Radicalism to Chinese Rule in Xinjiang." Asian Affairs 32, no. 2 (2005): 119135.

Smith Finley, Joanne. The Art of Symbolic Resistance: Uyghur Identities and Uyghur-Han Relations in Contemporary Xinjiang. Leiden: Brill, 2013.

Smith, Joanne N. "'Making Culture Matter": Symbolic, Spatial and Social Boundaries between Uyghurs and Han Chinese." Asian Ethnicity 3, no. 2 (2002): 153-174. 
Smith, Richard J. Chinese Maps: Images of "All under Heaven". Hong Kong: Oxford University Press, 1996.

State Administration for Religious Affairs. "2015 Chaojingongzuozongtuan Ping’an Fanhui Guonei, Jinnian Chaojinzuzhigongzuo Yuanmanjieshu (2015 Hajj Mission Safely Returned and the Organization of Hajj in 2015 Finished Successfully)." 21 October 2015.

—_. "Ningxiayinhang Huozhun Shidian Kaiban Yisilan Yinhangyewu (Hajj Work in Ningxia Hui Autonomous Region Has Been Well Prepared)." 31 August 2015. Statistics Bureau of Ningxia Hui Autonomous Region. Ningxia Tongji Nianjian (Ningxia Statistical Yearbook). Beijing: China Statistics Press, 2014.

Statistics Bureau of Xinjiang Uyghur Autonomous Region. Xinjiang Tongji Nianjian (Xinjiang Statistical Yearbook). Beijing: China Statistics Press, 2014.

Stewart, Alexander Blair. Chinese Muslims and the Global Ummah: Islamic Revival and Ethnic Identity among the Hui of Qinghai Province. London: Routledge, 2017. Taynen, Jennifer. "Interpreters, Arbiters or Outsiders: The Role of the Min Kao Han in Xinjiang Society." Journal of Muslim Minority Affairs 26, no. 1 (2006): 45-62. Tontoni, Roberta. Muslim Sanzijing: Shifts and Continuities in the Definition of Islam in China. Leiden: Brill, 2016.

U.S. Commission on International Religious Freedom. 2016 Annual Report. Washington, DC: U.S. Commission on International Religious Freedom, 2016.

—. Annual Report 2012. Washington, DC: U.S. Commission on International Religious Freedom, 2012.

Veer, Peter van der. "Nationalism and Religion." In The Oxford Handbook of the History of Nationalism, edited by John Breuilli, 655-671. Oxford: Oxford University Press, 2013, 655-671. 
Waite, Edmund. "The Impact of the State on Islam Amongst the Uyghurs: Religious Knowledge and Authority in the Kashgar Oasis." Central Asian Survey 25, no. 3 (2006): 251-265.

Wayne, Martin I. China's War on Terrorism: Counter-Insurgency, Politics and Internal Security. London: Routledge, 2008.

Welcome to Islam. "Beijingshi Qingzhensi (Mosques of Beijing)."

http://www.yslzc.com/shu/Class103/zgqzs/200605/7842.html.

Wong, Edward. "China Offers Incentives to Intermarry in Xinjiang." International New York Times, 3 September 2014.

— December 2016.

— . "Xinjiang, Tense Chinese Region, Adopts Strict Internet Controls." New York Times, 10 December 2016.

Wong, How Man, and Adel Awni Dajani. Islamic Frontiers of China: Peoples of the Silk Road. London: I.B. Tauris, 2011.

Xinhua. "Ningxia Yuanjing: Sheli Yisilan Jinrongzhongxin (Ningxia Vision: The Establishment of an Islamic Financial Centre)." 26 November 2012.

—_. "Ningxiayinhang Huozhun Shidian Kaiban Yisilan Yinhangyewu (Ningxia Bank Has Been Officially Approved to Establish Its Pilot Islamic Banking Services)." 25 December 2009.

—_. "Xijinping Zai Di’erci Zhongyangxinjianggongzuozuotanhuishang Fabiao Zhongyaojianghua (Xi Jinping Delivered an Important Speech in the Second Xinjiang Work Seminar of the Сссрс)." 30 May 2014.

Xinjiang Ethnic Affairs Commission. "Xinjiang Youzuzhi Chaojingongzuo Wenbutuijin (Organized Hajj Work in Xinjiang Is Moving Forward Steadily." 3 July 2015. 
Yang, Zhijuan. "Zuqunrentong Yu Minzu De Jieding: Yi Huizu Weili (National Identity and the Demarcation of a Nation: A Case Study of Hui)." Huizu yanjiu (Journal of Hui Muslim Minority Studies) 40, no. 4 (2000): 4-8.

Yongjin, Zhang, and Barry Buzan. "The Tributary System as International Society in Theory and Practice." Chinese Journal of International Politics 5, no. 1 (2012): 3-36.

Zang, Xiaowei. Ethnicity and Urban Life in China: A Comparative Study of Hui Muslims and Han Chinese. London: Routledge, 2007.

_ . "Hui Muslim - Han Chinese Differences in Perceptions on Endogamy in Urban China." Asian Ethnicity 6, no. 1 (2005): 51-68.

—_. "Uyghur-Han Earnings Differentials in Ürümchi." China Journal 65 (2011): 141155.

Zhu, Yuchao, and Dongyan Blachford. "Economic Expansion, Marketization, and Their Social Impact on China's Ethnic Minorities in Xinjiang and Tibet." Asian Survey 52, no. 4 (2012): 714-733. 